\title{
The structural geometry, metamorphic and magmatic evolution of the Everest massif, High Himalaya of Nepal-South Tibet
}

\author{
M. P. SEARLE ${ }^{1}$, R. L. SIMPSON ${ }^{1}$, R. D. LAW ${ }^{2}$, R. R. PARRISH ${ }^{3}$ \& D. J. WATERS ${ }^{1}$ \\ ${ }^{1}$ Department of Earth Sciences, Oxford University, Parks Road, Oxford OXI 3PR, UK \\ (e-mail: mike.searle@earth.ox.ac.uk) \\ ${ }^{2}$ Department of Geological Sciences, Virginia Tech., Blacksburg, Virginia 24061, USA \\ ${ }^{3}$ Department of Geology, Leicester University, Leicester LE1 7RH, and NERC Isotope Geosciences Laboratory, Keyworth, \\ Nottingham, NG12 $5 G G$
}

\begin{abstract}
This paper presents a new geological map together with cross-sections and lateral sections of the Everest massif. We combine field relations, structural geology, petrology, thermobarometry and geochronology to interpret the tectonic evolution of the Everest Himalaya. Lithospheric convergence of India and Asia since collision at c. $50 \mathrm{Ma}$. resulted in horizontal shortening, crustal thickening and regional metamorphism in the Himalaya and beneath southern Tibet. High temperatures $\left(>620^{\circ} \mathrm{C}\right)$ during sillimanite grade metamorphism were maintained for 15 million years from 32 to $16.9 \pm 0.5$ Ma along the top of the Greater Himalayan slab. This implies that crustal thickening must also have been active during this time, which in turn suggests high topography during the Oligocene-early Miocene. Two low-angle normal faults cut the Everest massif at the top of the Greater Himalayan slab. The earlier, lower Lhotse detachment bounds the upper limit of massive leucogranite sills and sillimanite-cordierite gneisses, and has been locally folded. Ductile motion along the top of the Greater Himalayan slab was active from 18 to 16.9 Ma. The upper Qomolangma detachment is exposed in the summit pyramid of Everest and dips north at angles of less than $15^{\circ}$. Brittle faulting along the Qomolangma detachment, which cuts all leucogranites in the footwall, was post-16 Ma. Footwall sillimanite gneisses and leucogranites are exposed along the Kharta valley up to $57 \mathrm{~km}$ north of the Qomolangma detachment exposure near the summit of Everest. The amount of extrusion of footwall gneisses and leucogranites must have been around $200 \mathrm{~km}$ southwards, from an origin at shallow levels (12-18 km depth) beneath Tibet, supporting models of ductile extrusion of the Greater Himalayan slab. The Everest-LhotseNuptse massif contains a massive ballooning sill of garnet + muscovite + tourmaline leucogranite up to $3000 \mathrm{~m}$ thick, which reaches $7800 \mathrm{~m}$ on the Kangshung face of Everest and on the south face of Nuptse, and is mainly responsible for the extreme altitude of both mountains. The middle crust beneath southern Tibet is inferred to be a weak, ductile-deforming zone of high heat and low friction separating a brittle deforming upper crust above from a strong (?granulite facies) lower crust with a rheologically strong upper mantle. Field evidence, thermobarometry and $\mathrm{U}-\mathrm{Pb}$ geochronological data from the Everest Himalaya support the general shear extrusive flow of a mid-crustal channel from beneath the Tibetan plateau. The ending of high temperature metamorphism in the Himalaya and of ductile shearing along both the Main Central Thrust and the South Tibetan Detachment normal faults roughly coincides with initiation of strike-slip faulting and eastwest extension in south Tibet $(<18 \mathrm{Ma})$.
\end{abstract}

Keywords: Everest, Himalaya, geological map, leucogranite, extension, compression.

Recent interpretations of the structure of the Greater Himalayan metamorphic sequence as a mid-crustal layer forming a ductile extruding channel (Nelson et al. 1996; Grujic et al. 1996, 2002; Beaumont et al. 2001) are examined in the Everest region of Nepal and South Tibet. It has been widely recognized that the metamorphic core of the Himalaya (Fig. 1) is bounded by two major, north-dipping shear zones, the Main Central Thrust along the base, characterized by inverted metamorphism and top-tosouth shear fabrics, and the South Tibetan Detachment normal faults along the top, characterized by right way-up metamorphism with both pure shear flattening fabrics and down-to-north simple shear extension. Burchfiel \& Royden (1985), Burchfiel et al. (1992) and Hodges et al. (1992) suggested that the Main Central Thrust and South Tibetan Detachment were acting simultaneously, resulting in the southward extrusion of a wedge of crustal rocks. Both the Main Central Thrust and South Tibetan Detachment show intense high strain zones, which have been responsible for condensing or telescoping the metamorphic isograds (eg: Searle \& Rex 1989; Walker et al. 1999; Stephenson et al. 2000, 2001). Pressure-temperature $(P-T)$ profiles across the Greater Himalaya are remarkably consistent along the orogen (e.g. Hodges et al. 1988; Hubbard 1989; Searle et al. 1992, $1999 b$; Metcalfe 1993). They generally exhibit inverted $T$ and $P$ across the narrow Main Central Thrust high-strain zone at the base, with a wide zone of roughly isothermal temperatures in the sillimanite grade gneisses and migmatites across the middle of the slab. Pressures decrease normally up structural section to the north of the Main Central Thrust, and both $T$ and $P$ drop off rapidly across the South Tibetan Detachment normal fault shear zones at the top of the slab. Geochronological constraints indicate that both shear zones were active simultaneously around 22-17 Ma (Hubbard \& Harrison 1989; Hodges et al.1992, 1993, 1996; Walker et al. 1999; Murphy \& Harrison 1999; Simpson et al. 2000). Hurtado et al. (2001) and Hodges et al. (2001) further suggested that these faults could still be active today.

Deep seismic reflection profiling across southern Tibet from 


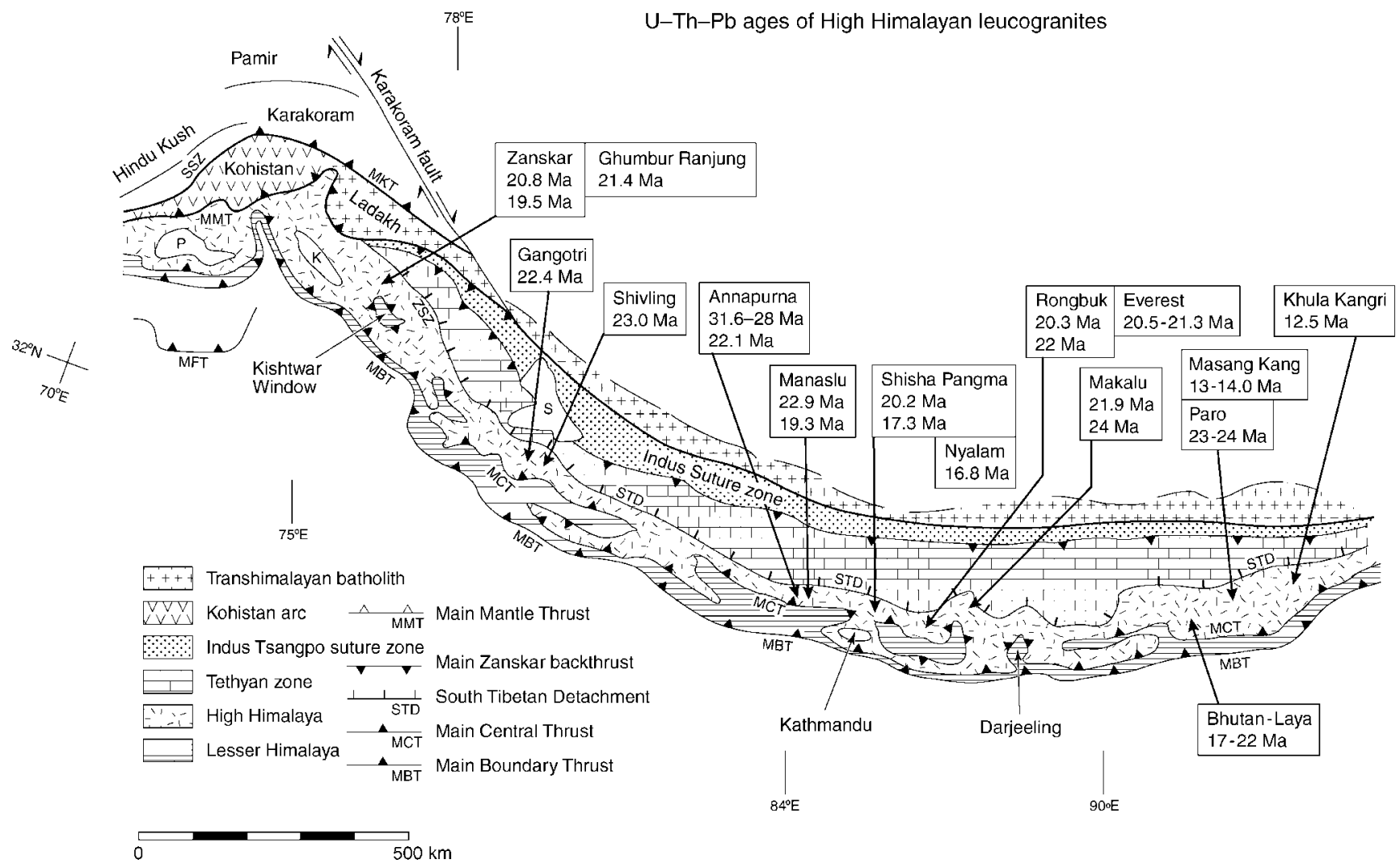

Fig. 1. Geological map of the Himalaya, showing $\mathrm{U}-\mathrm{Th}-\mathrm{Pb}$ ages of the dated leucogranites along the High Himalaya. Ages from Zanskar are from Noble \& Searle (1995) and Walker et al. (1999), Gangotri and Shivling from Searle et al. (1999a), Annapurna from Hodges et al. (1996), Manaslu from Harrison et al. (1999), Shisha Pangma from Searle et al. (1997), Rongbuk from Hodges et al. (1998) and Murphy \& Harrison (1999), Everest from Simpson et al. (2000), Makalu from Schärer (1984), Masang Kang, Paro and Laya in Bhutan (R.R. Parrish data), and Khula Kangri from Edwards \& Harrison (1997).

project INDEPTH (Zhao et al. 1993; Nelson et al. 1996), combined with broadband earthquake and magnetotelluric data (Wei et al. 2001) have suggested that a high-conductivity layer at $15-20 \mathrm{~km}$ depth reflects partial melts and/or aqueous fluids in the middle crust of southern Tibet (Nelson et al. 1996; Alsdorf \& Nelson 1999). High geothermal activity and high heat flow (Francheteau et al. 1984) at shallow levels in the crust are most likely due to aqueous fluids. Satellite magnetic data reveal a low over Tibet indicating hot crust, and the deeper levels of the highconductivity zone have been interpreted as in situ partial melting (Alsdorf \& Nelson 1999). Several factors such as radiogenic heating and crustal thickening and shortening could have induced the high temperatures at these mid-crustal levels beneath southern Tibet. Seismological data indicate that relatively fast (cool) upper mantle extends from the Himalaya northwards to roughly the centre of the Tibetan plateau (Owens \& Zandt 1997; Kosarev et al. 1999). The crustal structure of southern Tibet, as determined from the INDEPTH profile (Fig. 2), contains several reflectors, which have been successfully matched to the major faults of the Himalaya to the south, notably the South Tibetan Detachment and the Main Himalayan Thrust (Hauck et al. 1998; Alsdorf et al. 1998). It has been suggested that the 'bright spots' imaged on the INDEPTH profile beneath south Tibet are leucogranites forming today (Nelson et al. 1996), at a similar structural horizon and depth to the High Himalayan leucogranites which crystalized during the Miocene and were extruded southward to their present position along the High Himalaya (Searle et al. 1993, 1997; Searle 1999a). It has further been suggested that ages of crustal melt leucogranites in the footwall of the South Tibetan Detachment decrease to the north (Wu et al. 1998) and that the Greater Himalayan crystalline rocks bounded by the South Tibetan Detachment above and the Main Central Thrust below have been effectively extruded southwards from beneath the middle crust of south Tibet (Nelson et al. 1996; Grujic et al. 1996, 2002; Searle 1999a, b; Hodges et al. 2001; Beaumont et al. 2001).

Burchfiel \& Royden (1985) were the first to propose the extrusion of the Himalayan wedge beneath the South Tibetan Detachment system of normal faults. Hodges et al. (1992) and Burchfiel et al. (1992) developed this idea after mapping several South Tibetan Detachment sections in southernmost Tibet. Searle et al. (1988), Searle \& Rex (1989), Walker et al. (1999) and Stephenson et al. $(2000,2001)$ linked the thrust motion on the Main Central Thrust with normal faulting along the South Tibetan Detachment by mapping metamorphic isograds across the Zanskar region, and they proposed that southward extrusion of the partially molten mid-crustal slab was responsible for the large-scale (40 km wavelength) SW-vergent recumbent folding of metamorphic isograds. Grujic et al. (1996), working in the Bhutan Himalaya, proposed a channel flow model with the highest extrusion velocities in the centre of the channel, based mainly on quartz petrofabric data. Their model is entirely compatible with the Searle \& Rex (1989) folded isograds model. Hodges et al. (2001) and Grujic et al. (2002) later proposed that, 
\begin{tabular}{l|l|l}
\hline & NEPAL & TIBET
\end{tabular}

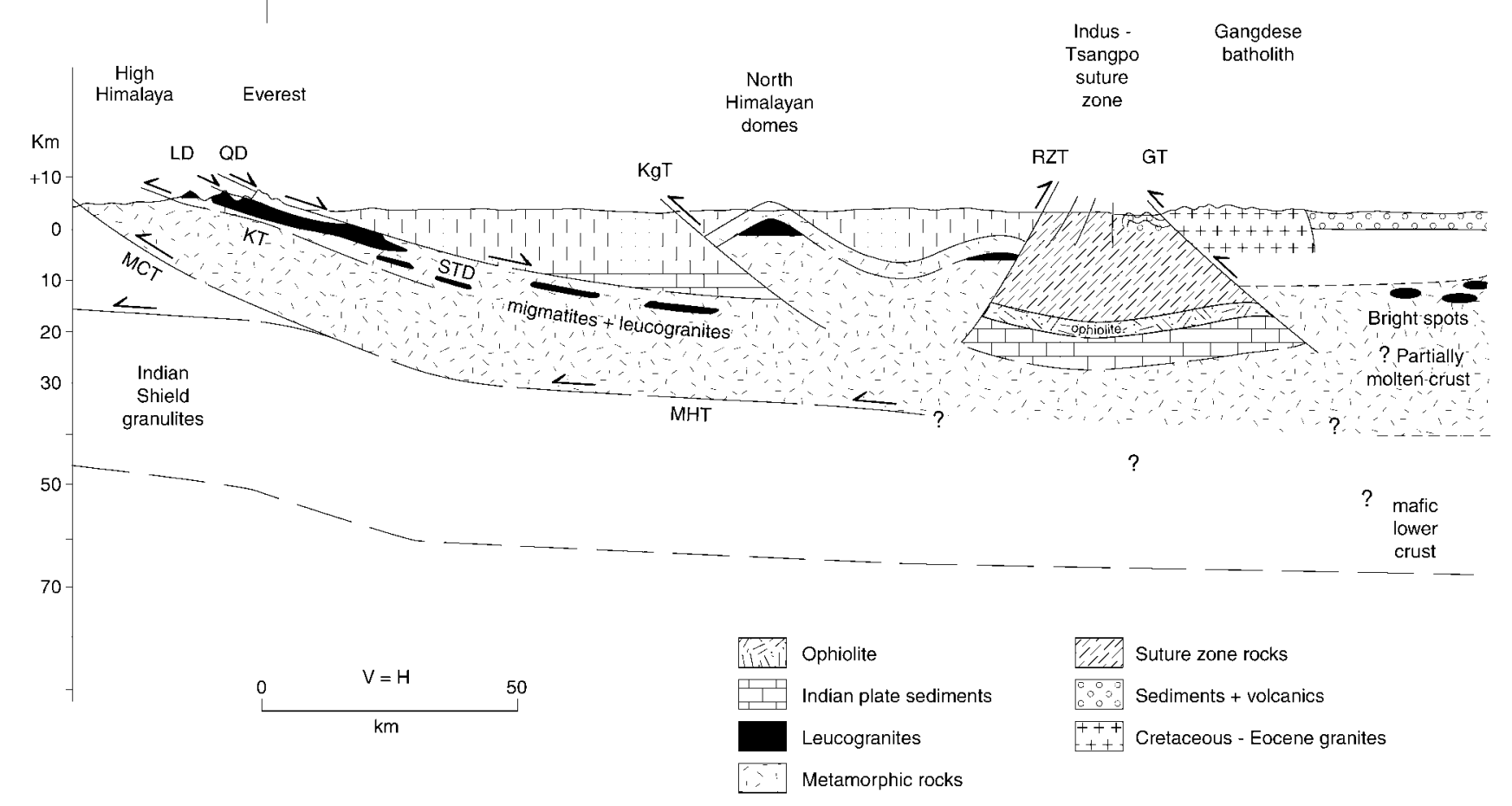

Fig. 2. Interpreted geological cross-section from the INDEPTH deep seismic profile north of the Himalaya (after Hauck et al. 1998). Crustal melt leucogranites in the High Himalaya are at similar structural horizon to the bright spots imaged beneath southern Tibet. LD, Lhotse detachment; QD, Qomolangma detachment; MHT, Main Himalayan Thrust; MCT, Main Central Thrust; KgT, Kangmar Thrust; RZT, Renbu-Zedong Thrust; GT, Gangdese Thrust.

rather than a wedge, a low-viscosity, mid-crustal channel was extruding to the south, linked to high uplift and erosion along the Himalaya. Vannay \& Grasemann (2001) noted the combination of both simple shear and pure shear and proposed a general shear extrusion model. Beaumont et al. (2001) summarized a thermal-mechanical model for the Himalaya in which channel flow and ductile extrusion were dynamically linked to topography and focused surface denudation.

These models can be tested using a combination of structural geology, thermobarometry and geochronology. In this paper we present the results of four field seasons mapping around the Everest massif, both in Nepal and southern Tibet. A new geological map of the Everest massif (Fig. 3), together with cross-sections and lateral sections (Fig. 4) are presented here. We use new structural, metamorphic and thermobarometric data from the Everest region to determine the $P-T$ conditions, the thermal structure and the depths of formation of the footwall rocks beneath the South Tibetan Detachment. We use these data to quantify the amount of dip-slip along the fault and hence the minimum amounts of southward extrusion of these mid-crustal rocks. We also use $\mathrm{U}-\mathrm{Th}-\mathrm{Pb}$ and ${ }^{40} \mathrm{Ar} /{ }^{39} \mathrm{Ar}$ dating of metamorphic rocks and leucogranites in the footwall of the South Tibetan Detachment (Hodges et al. 1998; Murphy \& Harrison 1999; Simpson et al. 2000) to provide time constraints of metamorphism, melting, cooling and ductile-brittle shearing along the South Tibetan Detachment, and vorticity analysis to constrain the distribution of pure and simple shear across the slab (Law et al. 2001, 2002) We use all this data from the Everest region to evaluate models for channel flow and ductile extrusion of the crust.

\section{The Everest massif structure and lithologies}

Pioneering geological work on Everest was carried out by Wager (1934, 1965), Odell (1948) and Lombard (1958) and during mountaineering expeditions on the Tibetan side of the massif. The stratigraphy of the sedimentary rocks on the north side of Everest was studied by Wang \& Zhen (1975) and Yin \& Kuo (1978). Polino (1981) published a map of the Imja Khola, south of Nuptse, and Lombardo et al. (1993), Pognante \& Benna (1993) and Carosi et al. (1998, 1999a, b) studied the structure and metamorphism of rocks from the Rongbuk valley in Tibet and the Khumbu valley in Nepal. Hubbard (1989) published thermobarometric constraints on the profile from the Main Central Thrust to the southern slopes of the Everest massif. Burchfiel et al. (1992) mapped the structures along the hanging wall of the South Tibetan Detachment in the Rongbuk valley. Hodges et al. (1998) published ${ }^{40} \mathrm{Ar} /{ }^{39} \mathrm{Ar}$ ages from the Rongbuk valley and Murphy \& Harrison (1999) dated monazites using in situ $\mathrm{Th}-\mathrm{Pb}$ methods from leucogranites in the Rongbuk monastery cliffs. Reconnaissance mapping of the Nepalese side of the Everest massif, extending west to Cho Oyu and east to Makalu, was carried out by Searle $(1999 a, b)$. More detailed mapping, using 1:20000 scale aerial photographs (courtesy of Bradford Washburn and Swissphotos) and groundtruthing, was carried out by M.P. Searle over four field seasons on both the Nepal and Tibet sides of the mountain. The map (Fig. 3) and sections (Fig. 4) are presented here.

Earlier studies in south Tibet defined one large-scale low-angle fault, the South Tibetan detachment, which places unmetamorphosed Palaeozoic sediments above high-grade gneisses and 


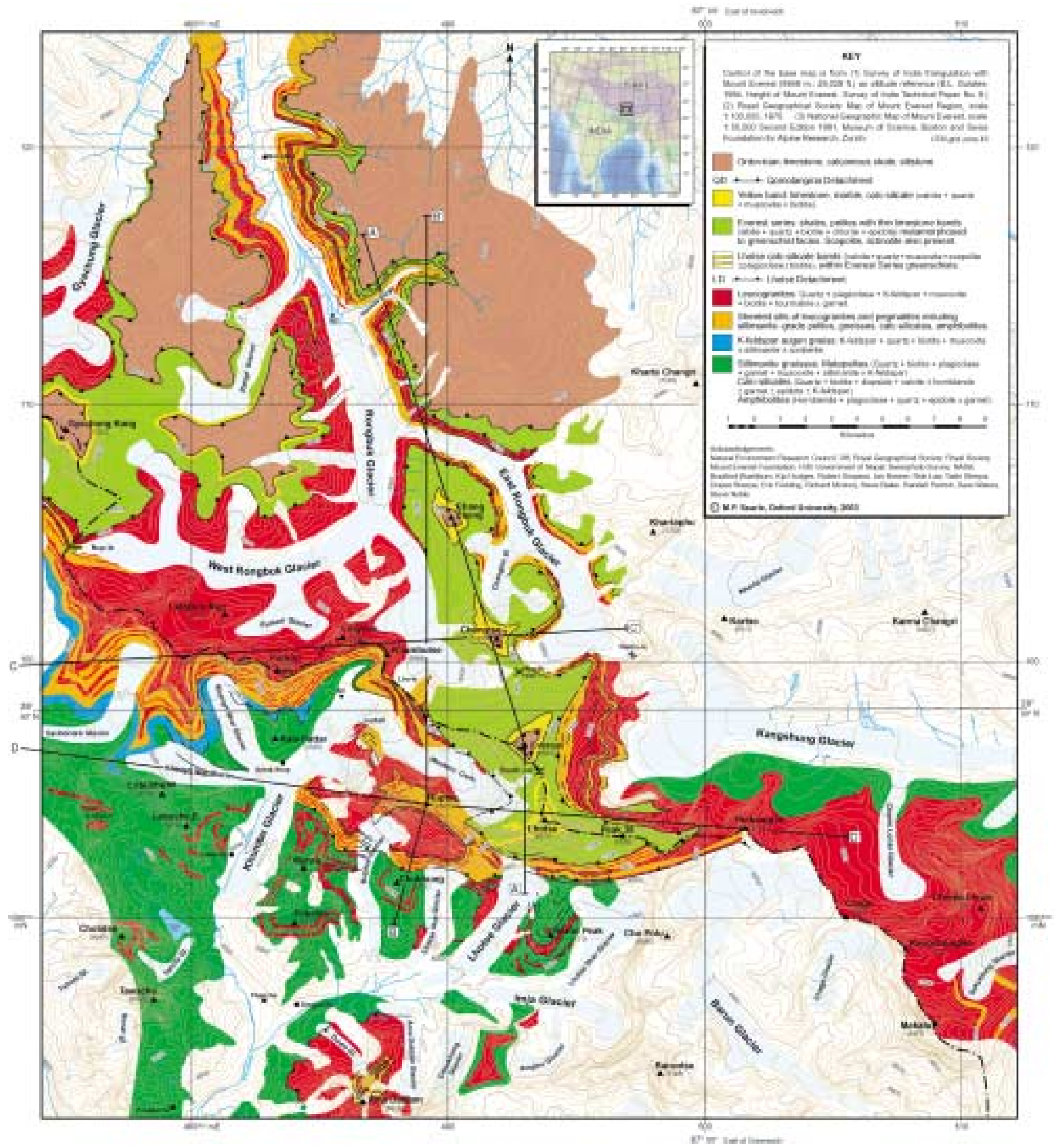

Fig. 3. Geological Map of the Mount Everest region, Nepal and South Tibet.

leucogranites (Burg 1983; Burg et al. 1984; Burchfiel et al. 1992; Hodges et al. 1998). To the west of Everest in the Shisha Pangma region one major fault places unmetamorphosed sediments directly on top of 20-17 Ma leucogranite (Searle et al. 1997). Along the Friendship Highway (Lhasa to Kathmandu road), the South Tibetan Detachment has similar structural relationships, with only one major fault (Burg et al. 1984; Burchfiel et al. 1992). Traced east to the Everest region, the
South Tibetan Detachment consists of two major normal faults (Fig. 5a and b), the upper Qomolangma detachment which places Ordovician sedimentary rocks above greenschist-facies carbonates and shales, and the lower Lhotse detachment which places the Everest series greenschists above high-grade sillimanitecordierite gneisses with more than 50\% leucogranite sills and sheets (Figs 3 and 4; Searle 1999a, b). A small angular discordance between the footwall Yellow Band and bedding in 

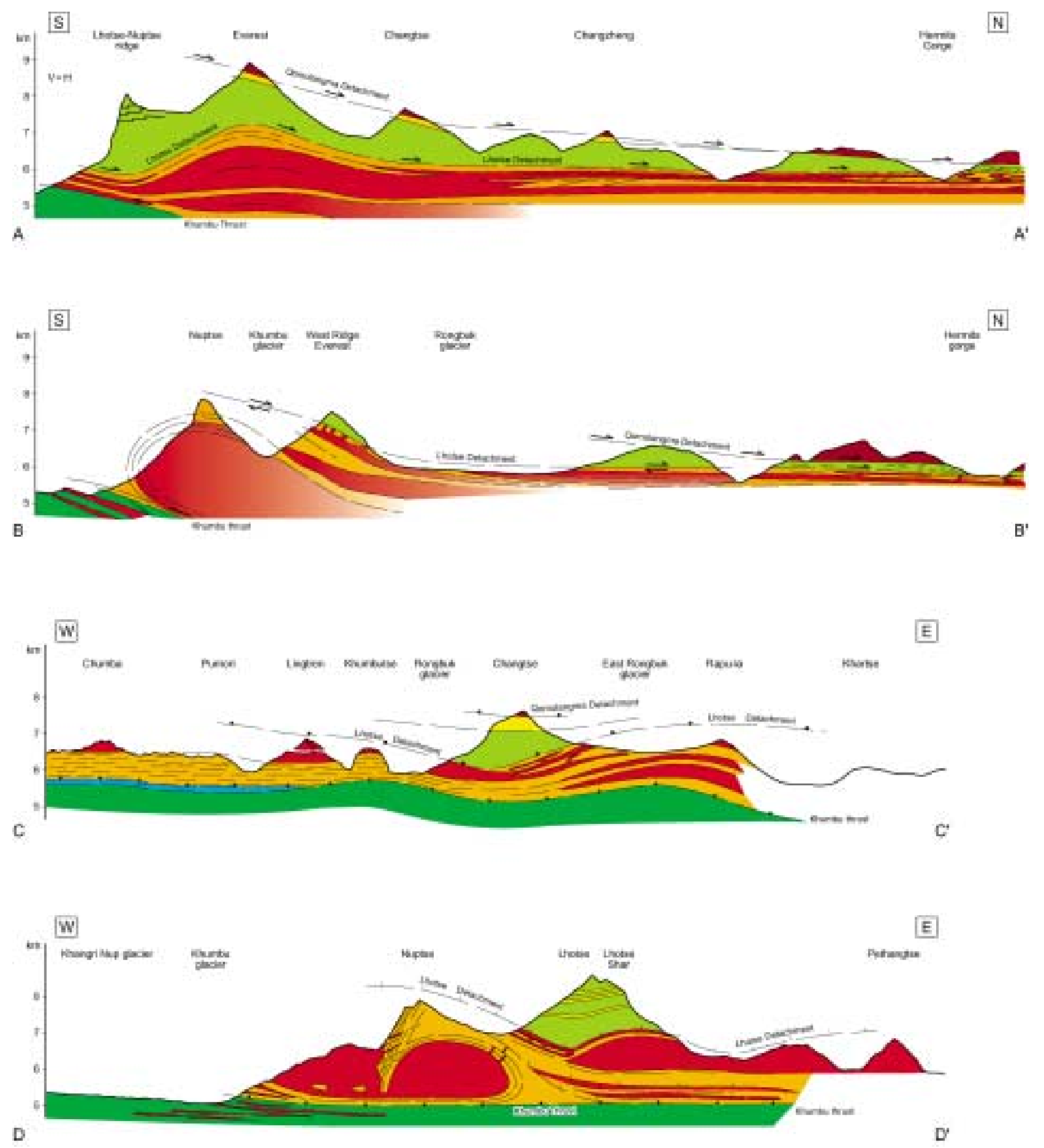

Fig. 4. Cross-sections $\left(A-A^{\prime}\right.$ and $\left.B-B^{\prime}\right)$ and lateral sections $\left(C-C^{\prime}\right.$ and $\left.D-D^{\prime}\right)$ across the Everest massif; see Figure 3 for lines of section and key to lithological units.

the hanging-wall Ordovician sedimentary rocks can be seen across the Qomolangma detachment on the north face of Everest (Fig. 5c). The dip of the Qomolangma detachment on the upper slopes of Everest (Fig. 5c) and on the peak of Gyachung Kang, west of Everest (Fig. 5d) is between 10 and $12^{\circ} \mathrm{N}$ shallowing to $4-5^{\circ} \mathrm{N}$ on the peak of Changtse and between $3^{\circ} \mathrm{N}$ and horizontal along the Rongbuk glacier and to the north (Fig. 5e and f). The Qomolangma detachment merges with the Lhotse detachment north of Rongbuk monastery to form one large shear zone (Fig. $5 \mathrm{~g}$ ), which places the highly folded sediments of the north Indian plate margin (Fig. 5h) directly over the high-grade gneisses and leucogranites of the Greater Himalayan slab. Along the NepalTibet border the South Tibetan Detachment dips consistently north and matches a prominent reflector in the INDEPTH profile to the east, which dips at around $10^{\circ} \mathrm{N}$ (Zhao et al. 1993; Nelson et al. 1996; Hauck et al. 1998). A south-vergent thrust, the 
Khumbu Thrust, has been mapped along the south face of Nuptse-Lhotse and traced westwards to beneath the south face of Cho Oyu within the Greater Himalayan slab (Searle 1999a, $b$ ). This out-of-sequence thrust was responsible for the southward transport of the Everest leucogranite sheets over the sillimanite gneisses with few leucogranites. Structures within the lower part of the Greater Himalayan slab are more difficult to map because of exposure problems, but the metamorphic grade remains fairly constant (in the sillimanite grade) for over $45 \mathrm{~km}$ from the Khumbu thrust south to the Main Central Thrust zone.

\section{Main Central Thrust zone}

The Main Central Thrust zone is a zone of high strain between 3 and $5 \mathrm{~km}$ thick which contains a penetrative shear foliation, which dips between 10 and $30^{\circ}$ to the north (Hubbard 1988, 1989; Pognante \& Benna 1993). Kinematic indicators ubiquitously indicate a top-to-the south shear sense consistent with thrusting of the metamorphic rocks of the High Himalaya south over the weakly metamorphosed or unmetamorphosed rocks of the Lesser Himalaya. The Main Central Thrust zone is coincident with a zone of inverted metamorphism where the isograds have been sheared and telescoped (Hubbard 1996). It contains a variety of lithologies including augen gneiss, quartzite, amphibolite, calc-silicate, pelite and marble. Augen gneisses crop out at several different levels within the Greater Himalayan slab. Hubbard $(1988,1989)$ identified the Main Central Thrust zone which she mapped separating the low-grade muscovite phyllites and psammites of the Lesser Himalaya below from the migmatites and sillimanite grade gneisses of the core of the slab above. Metamorphic grade increases sharply up structural section across the Main Central Thrust zone from chlorite to sillimanite grade and the section contains an inversion of both temperature and pressure. Deformation and shearing along the Main Central Thrust zone occurred during and after peak metamorphism. We distinguish the Main Central Thrust zone from the Main Central Thrust, which is the structurally lowest plane of high strain, and places rocks metamorphosed during the Tertiary Himalayan event southwards over essentially unmetamorphosed rocks of the Lesser Himalaya.

The lowermost unit within the Main Central Thrust zone is the Phaplu augen gneiss consisting of $\mathrm{Qtz}+\mathrm{Bt}+\mathrm{Ms}+\mathrm{Kfs}+\mathrm{Pl}+$ Tur \pm Grt which is variably mylonitized. Amphibolites contain the assemblage $\mathrm{Bt}+\mathrm{Hbl}+\mathrm{Ep}+\mathrm{Qtz}$ with some also containing actinolite. The Phaplu augen gneiss, similar to the Ulleri augen gneiss in west Nepal, is lithologically identical to augen gneisses higher up in the Greater Himalayan slab and must be structurally part of the Greater Himalayan slab unit, not part of the Lesser Himalaya beneath the Main Central Thrust as described by Catlos et al. (2002). Several marble horizons consist mainly of calcite but may also contain scapolite and muscovite. Impure quartzites contain $\mathrm{Qtz}+\mathrm{Bt}+\mathrm{Ms} \pm \mathrm{Grt} \pm \mathrm{Pl} \pm \mathrm{Kfs}$. Psammitic bands may also contain staurolite and garnet, and pelites contain the assemblage: Qtz $+\mathrm{Bt}+\mathrm{Grt}+\mathrm{St}+\mathrm{Ms}+\mathrm{Chl}$. Kyanite appears structurally above staurolite towards the top of the Main Central Thrust zone and the sillimanite-in isograd generally coincides with the top of the high strain Main Central Thrust zone. The assemblage: $\mathrm{Qtz}+\mathrm{Bt}+\mathrm{Pl}+\mathrm{Sil}+$ Grt marks the uppermost levels of the sheared zone characterized by an inverted metamorphic gradient (Hubbard 1988, 1989). Migmatites structurally above this are part of the high-grade core of the Greater Himalayan zone.

\section{Namche migmatites}

Structurally above the Main Central Thrust zone with its zone of inverted metamorphism, the Namche migmatites and orthogneisses consist of the assemblage: Qtz $+\mathrm{Pl}+\mathrm{Kfs}+\mathrm{Bt} \pm \mathrm{Grt} \pm$ $\mathrm{Sil} \pm \mathrm{Crd} \pm \mathrm{Ms}$. The presence of cordierite suggests that partial melting occurred under high-temperature low-pressure conditions consistent with the presence of sillimanite. The migmatites are characterized by stromatic textures with banded leucosomes, sometimes containing spectacular $\mathrm{C}-\mathrm{S}$ fabrics, which usually indicate a south-directed vergence; extensional crenulations indicating a north-directed vergence are occasionally observed, however (Fig. 6a). Garnet is frequently present and the presence of sillimanite and cordierite indicates high temperatures $\left(c .700^{\circ} \mathrm{C}\right)$ consistent with vapour-absent partial melting at pressures of $<5$ kbar. The original granitic protolith of the Namche migmatites was probably Cambrian in age and $\mathrm{Nd}$ model ages suggest that it formed from continental crust not older than $1.9-2.5 \mathrm{Ga}$ (Ferrara et al. 1983). Viskupic \& Hodges (2001) reported monazite and xenotime ${ }^{207} \mathrm{U} /{ }^{235} \mathrm{~Pb}$ ages of $25.4 \pm 0.11 \mathrm{Ma}$. and $22.11 \pm 0.22 \mathrm{Ma}$. from leucosomes separated from the Namche migmatites. Their data comprise nearly concordant $\mathrm{U}-\mathrm{Pb}$ isotopic ratios for 13 single monazite and xenotime crystals that range in age from 28.4 to $17.6 \mathrm{Ma}$. Temperature estimates from yttrium contents of dated monazites range from 677 to $535^{\circ} \mathrm{C}$. As only the higher of these temperatures is consistent with experimental constraints on the conditions necessary to produce anatectic melts of appropriate composition, Viskupic \& Hodges (2001) conclude that the c. 25.4-24.8 Ma dates for the grains with high apparent equilibrium temperatures provide the best estimates for the age of anatexis. Despite having similar ages to several of the tourmaline leucogranites higher up the section in the Everest region (Fig. 6b), there appears to be no direct structural connection between the Namche migmatites and the high-level leucogranites. $\mathrm{Rb} / \mathrm{Sr}$ biotite-whole rock isochrons record the time of cooling through $300-350{ }^{\circ} \mathrm{C}$ at c. $15.8 \mathrm{Ma}$ (Tonarini et al. 1994).

\section{Sillimanite gneisses}

Metapelitic sillimanite grade paragneisses attain a structural thickness of nearly $15 \mathrm{~km}$ above the Namche migmatites. These black coloured schists and gneisses are rich in biotite and contain variable amounts of fibrolitic sillimanite. Garnet is common at the base but becomes scarcer towards the top, where cordierite appears. Small euhedral green tourmaline grains cluster in micarich zones where they have presumably scavenged boron. Kyanite, microcline, zircon, monazite and opaque minerals are variably present with epidote, actinolite and chlorite being present as secondary alteration minerals. The pattern of preferred quartz $c$-axis orientation in the gneisses beneath the Lhotse Detachment indicates that penetrative deformation was close to plane strain (Law et al. 2002). The sense of asymmetry is consistent with top down-to-north shear sense. Sillimanite grains have been drawn into the extensional shear bands but still appear pristine, suggesting that penetrative deformation occurred at close to peak metamorphic temperatures. Plastically deformed feldspars suggest temperatures above $450-500{ }^{\circ} \mathrm{C}$. There is little or no evidence for a later, lower temperature greenschist facies overprint. These 'quenched' fabrics support models for rapid exhumation along the footwall of the South Tibetan Detachment. The dominant microstructural shear sense indicators (extensional shear bands, mica fish, porphyroclast tails etc.) indicate topdown-to-NNE sense of shear. However, both top-to-north and 
top-to-south shear bands have developed contemporaneously (Law et al. 2001). Both ductile simple shearing and pure shear coaxial deformation are distributed through the Greater Himalayan sequence metamorphic rocks.

The sillimanite gneisses have been intruded by leucogranite sills and dykes which appear towards the top of the structural pile, north of Namche Bazar, and become very common right at the top around Everest Base Camp on the Khumbu glacier (Fig. 6c). Structural data from the Ama Dablam biotite + muscovite + tourmaline leucogranite (Fig. 6f) demonstrate that the outlying klippen of leucogranites exposed above sillimanite gneisses on Ama Dablam, Kangteiga and Tramserku, south of Everest (Fig. 3) are all part of the same leucogranite sheet. Aplite and pegmatite sills and dykes are also common (Fig. 6d) demonstrating that a metasomatic volatile-rich phase played an important role in leucogranite migration (Weinberg \& Searle 1999). In the Lingtren-Everest-Lhotse massif at least two prominent sets of leucogranite sills-dykes intrude the sillimanite gneisses (Fig. 6c and e). Earlier, set 1 sills are parallel to the dominant flat-lying schistosity and have a weak foliation-parallel fabric indicated by aligned micas, and later set 2 dykes cross-cut the ductile fabrics in the sillimanite gneisses. In the Kharta valley, NE of Everest, at least three sets of leucogranite dykes intrude the sillimanite gneisses (Fig. 6g) immediately beneath the South Tibetan detachment. The latter two sets both cross-cut ductile fabrics in the gneisses.

Several inclusions of granulites containing the assemblage: $\mathrm{Hbl}+\mathrm{Opx}+\mathrm{Cpx}+\mathrm{Pl}+\mathrm{Qtz}+\mathrm{Ilm} \pm \mathrm{Bt}$, enclosed in biotite + sillimanite gneisses were found in the Kharta valley (Fig. 6h). The original hornblende crystals have partially decomposed to form a mesh of ortho- and clinopyroxene and extremely calcic plagioclase. No garnet is present in these rocks. Lombardo \& Rolfo (2000) described re-equilibrated eclogites contain large garnets, but omphacite has been replaced by a recrystallized symplectite of plagioclase and diopside \pm orthopyroxene. Garnet crystals are surrounded by a corona of plagioclase rimmed by orthopyroxene. Plagioclase + biotite intergrowths have replaced phengite, and the amphibole matrix is composed of brown hornblende which replaces garnet + orthopyroxene and also grows on the diopside + plagioclase symplectite. These granulitized eclogites are not the same, petrologically or structurally as the Eocene UHP eclogites from Kaghan, Pakistan (O'Brien et al. 2001) or from Tso Morari, Ladakh (deSigoyer et al. 2000), and are likely to be pre-Himalayan eclogites, subsequently recrystallized and enclosed in Himalayan sillimanite grade gneisses.

Searle $(1999 a, b)$ mapped a prominent 'layered series' along the base of the leucogranites from Cho Oyu to the south face of Lingtren and Nuptse-Lhotse. These rocks include sillimanite gneisses, amphibolites and calc-silicates intruded by thin layerparallel sills of leucogranite. Higher up the section leucogranites become increasing more abundant and the pelitic gneisses occur only as xenolithic stringers enclosed wholly by the granite. The leucogranite sills amalgamate to form giant $2-3 \mathrm{~km}$ thick sills on the south faces of Lingtren, Khumbutse and Nuptse. Further east the same leucogranites increase in size in the MakaluChomolonzo massif where they reach a maximum thickness of around $3.5 \mathrm{~km}$, the vertical height of granite cliffs flanking the south side of the Kangchung valley (Fig. 7a-c). Sillimanite gneisses hosting leucogranite sills are also present on the Kangchung (east) face of Everest (Fig. 7d) and on the peak of Pethangtse, on the south side of the upper Kangchung glacier (Fig. 7e). On the north face of Cho Oyu (Fig. 7f) similar leucogranite sills intrude sillimanite gneisses almost up to the summit, where the Lhotse detachment is exposed at $8000 \mathrm{~m}$.

Along the Kharta valley, also called the Phung chu, sillimanite gneisses and leucogranites are exposed $57 \mathrm{~km}$ north of Makalu and Everest (Fig. 7g). Thus the South Tibetan detachment normal faults can be traced for a north-south distance of at least $57 \mathrm{~km}$ from $8500 \mathrm{~m}$ elevation, close to the summit of Everest, along the Rongbuk glacier (Fig. 7h), and from Makalu along the Kharta valley to a point near GPS location N28 $18^{\prime}$, E $87^{\circ} 21^{\prime}$ altitude $3742 \mathrm{~m}$.

\section{Everest Series and Yellow Band}

A series of dark coloured thin-bedded pelites and psammites are present structurally above the sillimanite gneisses and leucogranites, well exposed on the SW face of Everest (Fig. 5a). These were termed the Everest series by Wager $(1934,1965)$ and the North Col Fm. by Lombardo et al. (1993) and Carosi et al. (1998, 1999). Searle (1999a) noted the lower metamorphic grade of these rocks and the lack of leucogranites within them. He also mapped a large-scale, low-angle normal fault, the Lhotse Detachment, separating the sillimanite gneisses and leucogranites below from the biotite \pm garnet grade greenschists of the Everest series above. A few samples collected by climbers on the South col route above the South $\mathrm{Col}$ and on the SW face contain the assemblage: $\mathrm{Ab}+\mathrm{Qtz}+\mathrm{Bt}+\mathrm{Chl}+\mathrm{Ep} \pm \mathrm{Ms}$. None of our samples contain aluminium silicates or garnet. Some calcareous veins contain epidote, titanite and apatite. Two samples contain scapolite porphyroblasts and some samples with volcanoclastic protoliths also contain actinolite. The mineral assemblage precludes accurate thermobarometry, but the assemblage present suggests a middle or upper greenschist facies grade of metamorphism.

Three prominent thin bands of pale-coloured calc-silicate marbles occur on the Lhotse face in the western cwm on the north face of Lhotse and high on the south face of the LhotseNuptse ridge. They are thin marble bands within the Everest greenschists and have been deformed into south-verging chevron folds around the top of the Khumbu glacier region on Lhotse (Searle 1999a). These Lhotse calc-silicate bands are structurally

Fig. 5. (a) The Everest-Lhotse-Nuptse massif viewed from the south face of Pumori, above the Khumbu glacier, showing the two normal faults, the upper Qomolangma detachment (QD) and the lower Lhotse detachment (LD). (b) The Kangshung (east) face of Everest showing the domal shape of the Everest-Nuptse leucogranite (Lg), the Everest series (Es) greenschists above the Lhotse detachment (LD) and the upper Qomolangma detachment (QD) cutting through the summit region. The South col is left of the summit and the North col is visible on the right (photo: Leo Dickinson). (c) View south to the North face of Everest from the east Rongbuk glacier in Tibet with Changtse in the foreground. A slight angular discordance can be picked out between the Ordovician sediments on the summit and the bedding in the Yellow Band beneath the Qomolangma detachment (QD). The Lhotse detachment (LD) marks the upper limit of the sillimanite gneisses and leucogranites. (d) North face of Gyachung Kang in Tibet showing the thin wedge of Everest series greenschists (Es) between the upper Qomolangma detachment (QD) and the lower Lhotse detachment (LD). The massive leucogranite cliffs forming the basal $1500 \mathrm{~m}$ of the mountain are continuous eastwards into the Everest leucogranites. (photo: Marko Prezelj). (e \& f) Cliffs of leucogranite sills intruding sillimanite gneisses, footwall of the Lhotse detachment, above Advanced base camp, $6500 \mathrm{~m}$ on the east Rongbuk glacier. (g) Leucogranite sills on cliffs above Everest base camp on the Rongbuk glacier, Tibet. (h) Folded Tethyan sediments above the Qomolangma detachment, Tibetan plateau, north of Everest. 

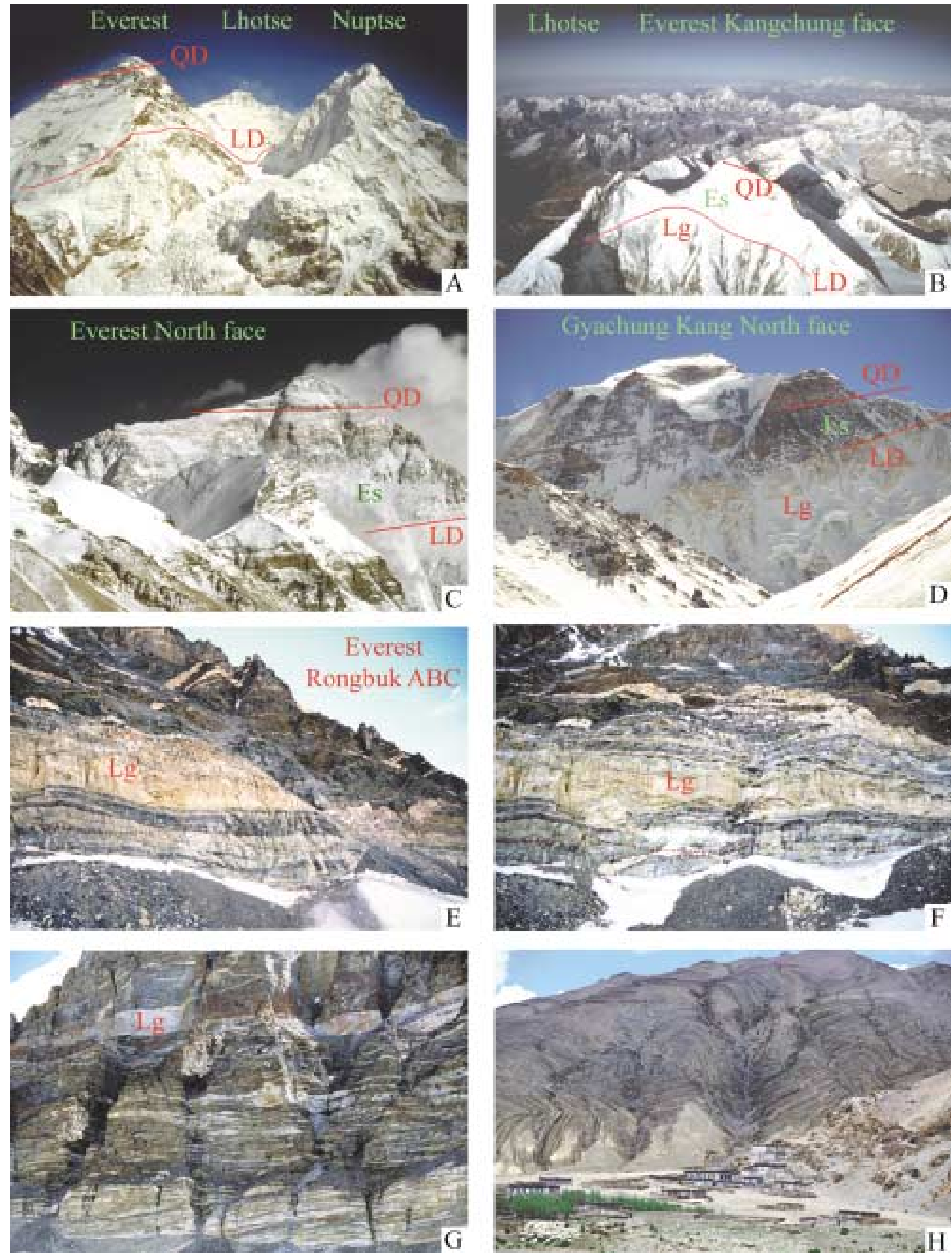

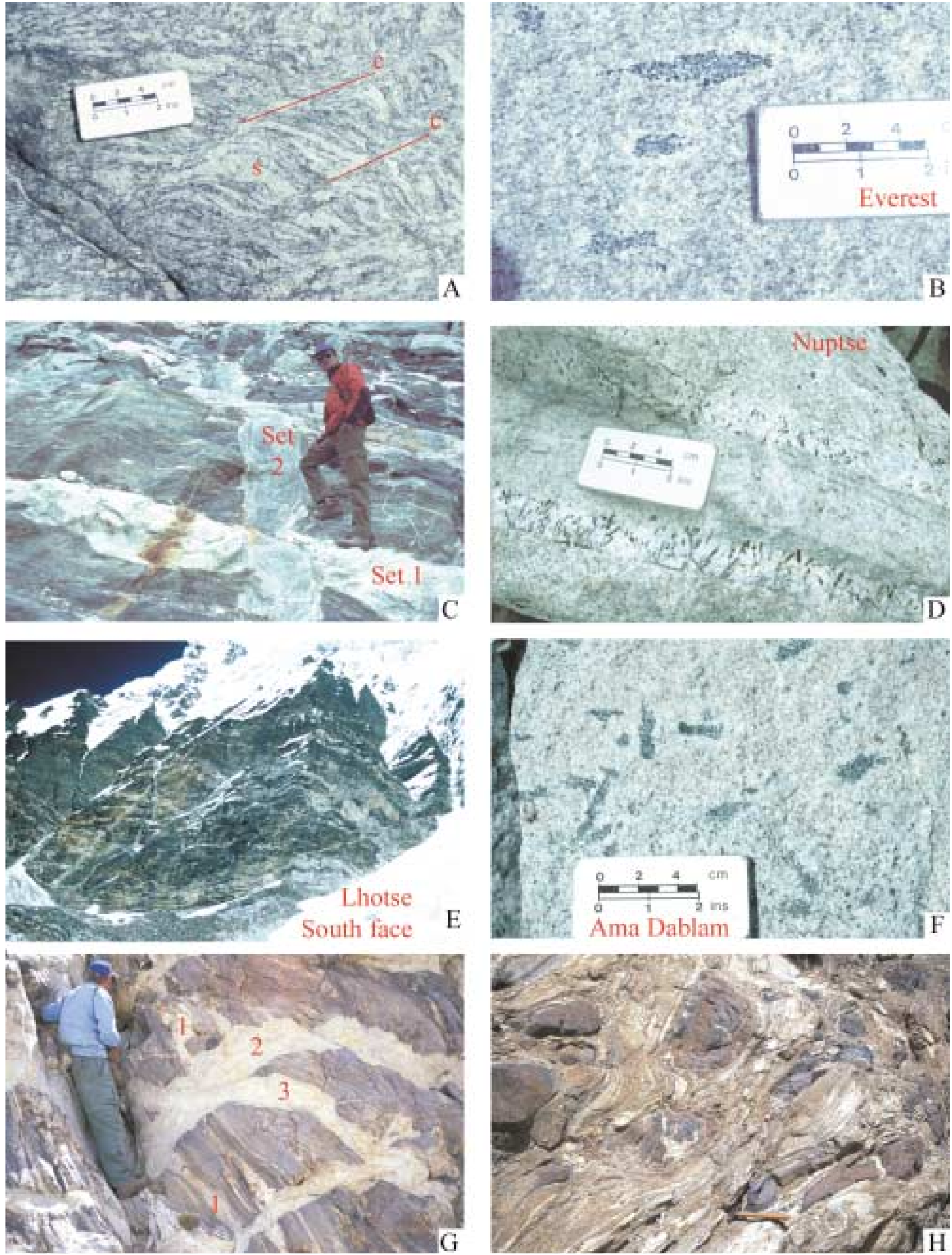
beneath the prominent Yellow Band, which lies just below the summit of Everest and dips north to below the summit of Changtse in Tibet.

The Yellow Band is a prominent marker, which encircles the summit rocks high up on Everest between c. 8200 and $8500 \mathrm{~m}$. This massive marble band approximately $200-250 \mathrm{~m}$ thick conformably lies on top of the Everest series greenschists and contains calcite, quartz, muscovite \pm biotite, and appears to be at a similar metamorphic grade to the underlying greenschists on the SW face of Everest. Despite the lack of diagnostic fossils, the Yellow Band limestones were originally thought to be Permian in age by Wager (1934) but are now regarded as Ordovician age by Wang \& Zhen (1975) and Burchfiel et al. (1992) using correlations with similar rocks to the north of Everest in Tibet, and with the lithologically similar the Sanctuary and Yellow Band Formations in the Annapurna region (Colchen et al. 1986). If this correlation is correct, then the Everest series greenschists must be either late Precambrian or Cambrian metamorphosed black shales.

\section{Everest summit rocks}

Rock samples collected from the summit of Everest are relatively unmetamorphosed impure limestones, often still containing fragments of conodonts and corals. These rocks are thought to be Ordovician in age based on correlation with fossiliferous rocks at the same structural horizon near Nyalam (Mu et al. 1973; Wang \& Zhen 1975). A sample collected close to the summit of Everest is a mylonitized dolomitic marble containing $88 \%$ calcite, $9 \%$ dolomite $2 \%$ quartz and $1 \%$ illite/muscovite. There is grain size reduction and preferred alignment of carbonate grains into a strong foliation with porphyroclasts of larger spheroidal carbonate grains rimmed by asymmetric strain shadows. The porphyroclasts contain deformation twins with wavy extinction suggesting that the grains have not fully annealed after strain. Small quartz grains are unstrained, and notable for the abundance of tiny fluid inclusions, some with vapour bubbles. The fact that marble has strained plastically but quartz has not suggests that temperatures during deformation were above $c .150{ }^{\circ} \mathrm{C}$ but less than c. $250^{\circ} \mathrm{C}$ (e.g. Ferril 1991; Burkhard 1993). The exact location of the Qomolangma Detachment on the summit pyramid of Everest is debateable. Photos of the North face show an angular discordance at c. $8500 \mathrm{~m}$ (Fig. 5c) with flatter-lying bedding in the Ordovician limestones above than the Yellow Band marble and the thin bedded shaley rocks of the Everest greenschists beneath. We have mapped the Qomolangma detachment as lying above the Yellow Band with the high strain mylonitized marbles probably extending up as far as the summit of Everest.

\section{Leucogranites}

The Everest area contains perhaps the largest proportions of leucogranites along the High Himalaya. They occur towards the structural top of the Greater Himalayan slab, mainly as extremely large layer-parallel sills up to $1200-1500 \mathrm{~m}$ thick or, less commonly, cross-cutting dykes intruding into sillimanite grade gneisses (Searle 1999a, b; Viscona \& Lombardo 2002). The thickest granite sill is the ballooning sill exposed on the south face of Nuptse, which reaches 2800-3000 m thick (Fig. 5a). This is the same leucogranite as the spectacular domed shaped granite exposed in the Kangshung east face of Everest, which extends almost as high as the South Col (Figs 2 and 5b). The leucogranites reach their most spectacular scale south of the Kangshung valley, where approximately $3000 \mathrm{~m}$ high vertical cliffs of leucogranite are exposed on the north face of Chomolonzo and Makalu (Fig. 7a and b). In the Khumbu glacier region, the narrows either side of the Khumbu icefall are leucogranite cliffs beneath the Lhotse Detachment, which ramps down to the east. The Everest greenschists are thickest on the SW face of Everest and across the western cwm on Lhotse. The shape of the bulbous leucogranite sills seems to control the dip of the Lhotse detachment above (Fig. $4 \mathrm{~b}$ and d).

Quartz, microcline or orthoclase and plagioclase are ubiquitous in the Everest granites, which also contain varying amounts of tourmaline, muscovite, biotite and garnet. Sillimanite, cordierite, apatite, monazite and zircon are also present. The Everest leucogranites are viscous minimum melts, probably produced by melting of a Qtz $+\mathrm{Ms}+\mathrm{Pl}$ pelitic protolith, similar to the underlying sillimanite gneisses in the presence of some amount of fluid. Mapping along the Khumbu and Ngozumpa glacier systems in Nepal and the Kangchung valley in Tibet has demonstrated that all the leucogranites, at least from Cho Oyu through Everest and Nuptse to Makalu and Chomolonzo (Fig. 3) are all part of the same sub-horizontal sheet lying along the top of the Greater Himalayan sequence, below the South Tibetan detachment low-angle normal fault (Searle 1999a, $b$ ). The base of these thick leucogranite sheets is marked by a zone of numerous layered sills intruding sillimanite gneisses with calc-silicate, amphibolite and rare quartzite bands. Emplacement occurred by hydraulic fracturing along foliation-parallel multiple sills exploiting layers of anisotropy. Parallel stringers of dark-coloured xenoliths of sillimanite gneisses, still retaining their parallelism with the country rock, suggest passive magmatic intrusion. The larger granite sills have ballooned out into huge bulbous protrusions, such as the spectacular Nuptse leucogranite (Fig. 4b and d; Searle $1999 a, b$ ). A volatile-rich metasomatic phase produced late growth of poikilitic K-feldspars, layered pegmatites and aplite dikes and an explosive network of dykes emanating out of the top of the Nuptse-Everest leucogranite (Searle 1999b; Weinberg \& Searle 1999).

Fig. 6. (a) Namche migmatites showing extensional crenulation schistosity superimposed on stromatic migmatite textures. (b) Typical leucogranite from above Everest base camp on the Khumbu glacier, Nepal showing 'ghosts' of tourmaline + quartz in a muscovite + biotite + garnet leucogranite. This sample (E 13) has U-Pb monazite and xenotime ages of 20.5-21.3 Ma. (c) Concordant set 1 leucogranite sills within sillimanite gneisses and calcsilicates which have been intruded and cross-cut by set 2 dykes, south face of Lingtren, Khumbu glacier, Nepal. The set 2 dyke here (E 11) has a U-Pb xenotime age of $16.5 \pm 0.2 \mathrm{Ma}$. (d) Aplite and pegmatite dykes intruding tourmaline leucogranites, south face of Lhotse. Euhedral black tourmaline crystals are growing at right angles to the dyke margin, whilst garnet and micas show a magmatic flow alignment in the aplites. (e) Leucogranite sill network intruding sillimanite gneisses with calc-silicates below the Lhotse detachment, south face of Lhotse. A sample from the lower sill (E 62) has a $\mathrm{U}-\mathrm{Pb}$ monazite age of $20.2 \pm 1.0 \mathrm{Ma}$. (f) Muscovite + biotite + garnet leucogranite with large tourmaline 'ghosts', Ama Dablam leucogranite, south of Everest. (g) Three sets of cross-cutting leucogranite dykes intruding sillimanite grade gneisses in the Kharta valley, Tibet. (h) Pods of two-pyroxene + hornblende granulites enclosed in sillimanite gneisses, Kharta valley, Tibet. 


\section{Metamorphism and thermobarometry}

The distribution of temperature and pressure across the Greater Himalayan slab has been investigated using cation exchange thermobarometry and average $P-T$ calculations using the computer program THERMOCALC (version 2.75) and the thermodynamic data set of Holland \& Powell (1998). Mineral analyses obtained from samples collected from a north-south traverse along the Dudh Kosi, Khumbu and Rongbuk valleys (Fig. 8a and Simpson 2002) can be obtained from the Society Library or the British Library Document Supply Centre, Boston Spa, Wetherby, West Yorkshire LS23 7BQ, UK as Supplementary Publication No. SUP 18184 (4 pages). It is also available online at http:// www.geolsoc.org.uk/SUP18184. They have been augmented by the microprobe analyses of Hubbard (1988) for the southern part of the traverse. Both sets of data have been plotted on Figure $8 b$ with temperature and pressure against distance from the Main Central Thrust zone across the Greater Himalayan slab.

Garnet-biotite exchange thermometry employed the calibration 5AV of Holdaway (2000), except for two samples (see Table 1) where full analyses of biotite and garnet were unavailable, for which the thermometer of Bhattacharya et al. (1992, HW formulation) was used. For garnet-cordierite thermometry the calibration of Perchuk \& Lavrent'eva (1983) was used.

Activities of mineral end members were calculated using the computer program AX (documentation accessible at http://www. earthsci.unimelb.edu.au/tpg/thermocalc/docs.pdf)), which incorporates activity models described in Holland \& Powell (1998). The mineral assemblages and calculated activities are available as a Supplementary Publication (see above), and were input into the program THERMOCALC in average $P-T$ mode. The results of both exchange thermometry and average $P-T$ calculation (including sufficient information to calculate uncertainty ellipses) are summarized in Table 1.

For computational reasons, THERMOCALC cannot use $\mathrm{Fe}-$ $\mathrm{Mg}$ exchange equilibria to place tight constraints on temperature. The THERMOCALC average $P-T$ result commonly makes use of net transfer devolatilization equilibria, and the calculated temperature is then sensitive to the composition of the fluid, which is generally unknown. In consequence, we have adopted the Grt-Bt exchange temperature from Holdaway (2000) as the principal estimate of metamorphic temperature, and have used THERMOCALC primarily to estimate pressure. Wherever the Grt-Bt temperature falls within the range of average $P-T$ solutions at accessible fluid compositions, we have quoted the result for which the temperature estimates match, giving the predicted $X\left(\mathrm{H}_{2} \mathrm{O}\right)$ (which carries a large uncertainty) in the final column of Table 1 . This procedure is broadly equivalent to using THERMOCALC in average- $P$ mode, but retains the advantage of plotting a $P-T$ uncertainty ellipse.

Garnet was not found in our samples from Rongbuk, nor in those from Lombardo et al. (1993) and Carosi et al. (1998). A single $P-T$ determination on a garnet-bearing rock from the Rongbuk valley was reported by Hodges et al. (1992).

An important test of absolute $P-T$ determinations is that they should be consistent with phase diagram constraints. Figure 9a shows the better constrained THERMOCALC $P-T$ results plotted against some key general reactions. There is good agreement between the $P-T$ results and the mineral stability fields, which lends credence to the $P-T$ results. Figure $9 \mathrm{~b}$ shows $P-T$ paths for the mid- to upper slab gneisses at Everest, inferred from phase equilibria and thermobarometry.

Some parts of the profile show open folding of the foliation so true structural thickness of the Greater Himalayan slab must be estimated. The maximum true structural thickness of the Greater Himalayan slab could be around $30-35 \mathrm{~km}$ depending on the geometry of the Main Central Thrust at depth. Exposure in the lower part of the profile around the Main Central Thrust is not good enough to define the exact location of the Main Central Thrust high-strain zone, but we assume it is located near the garnet isograd along the base of the inverted metamorphic sequence, as in other better exposed Main Central Thrust sections (e.g. Stephenson et al. 2000, 2001). The Main Central Thrust must lie structurally below the Phaplu augen gneiss, which is lithologically and metamorphically part of the Greater Himalayan slab unit.

These data indicate a rapid increase in temperature across the high strain Main Central Thrust zone from c. $450{ }^{\circ} \mathrm{C}$ up to c. $670{ }^{\circ} \mathrm{C}$. Temperatures remain roughly isothermal between 620 and $730{ }^{\circ} \mathrm{C}$ across about $50 \mathrm{~km}$ horizontal distance from the top of the Main Central Thrust zone to the South Tibetan Detachment normal fault at Rongbuk. The highest temperatures recorded in the profile are above $700{ }^{\circ} \mathrm{C}$ in the Namche migmatite orthogneiss, some $15 \mathrm{~km}$ north of the kyanite isograd. In general, kyanite-bearing samples from above the Main Central Thrust record $P-T$ conditions of $600{ }^{\circ} \mathrm{C}$ and c. $7 \mathrm{kbar}$, sillimanite-bearing samples record shallower, hotter conditions of $650{ }^{\circ} \mathrm{C}$ and c. $5 \mathrm{kbar}$ and cordierite-bearing samples from immediately beneath the South Tibetan Detachment at the top of the slab have peak metamorphic conditions of $660{ }^{\circ} \mathrm{C}$ and c. 4 kbar. The highest pressures ( $7-8 \mathrm{kbar}$ ), equivalent to $28-30 \mathrm{~km}$ depth, occur in the kyanite grade rocks at the top of the Main Central Thrust zone. Pressures then decrease northwards, from the Main Central Thrust up-section to around $3 \mathrm{kbar}$ at the top of the slab some $20 \mathrm{~km}$ structurally higher, where cordierite has grown at the expense of garnet, quartz and sillimanite. Linear regression yields an average pressure gradient of $0.20 \pm 0.09 \mathrm{kbar} \mathrm{km}^{-1}$ similar to a normal lithostatic pressure gradient of $0.27 \mathrm{kbar}$ $\mathrm{km}^{-1}$.

In the Makalu profile to the east of Everest, Goscombe \& Hand (2000) obtained much higher temperatures, also using THERMOCALC average $P-T$. Garnet, cordierite and sillimanite assemblages have overgrown low-pressure inclusion assemblages quartz, sillimanite and hercynitic spinel at temperatures as high as $837 \pm 59^{\circ} \mathrm{C}$ and pressures of $6.7 \pm 1.0 \mathrm{kbar}$ suggesting to these authors an anticlockwise $P-T$ path. These rocks then cooled isobarically to $600 \pm 45^{\circ} \mathrm{C}$ at $5.7 \pm 1.1 \mathrm{kbar}$. Goscombe $\&$ Hand (2000) include the entire inverted metamorphic zone from sillimanite $+\mathrm{K}$-feldspar grade to chlorite-biotite grade in the Lesser Himalaya beneath the Main Central Thrust. However,

Fig. 7. (a) North face of Makalu (left) and Chomolonzo (right) showing cliffs of 24 Ma. leucogranite, taken from a balloon above the Kangshung valley (photo: Leo Dickinson). (b) $2500 \mathrm{~m}$ high crags of leucogranite on the north face of Chomolonzo, Tibet. (c) Homogeneous leucogranite on Makalu's north face. Xenoliths of sillimanite gneisses are common in the lower outcrops above the Kangshung valley, Tibet. (d) The Kangshung (east) face of Everest showing leucogranite sills invading sillimanite gneisses (photo: Stephen Venables). (e) Horizontal leucogranite sills on the north side of Pethangtse, Kangshung glacier, Tibet (photo: Stephen Venables). (f) North face of Cho Oyu showing two large leucogranite sills intruding black gneisses; arrow points to two climbers at about $7300 \mathrm{~m}$ (photo: David Spencer). (g) Northernmost outcrops of STD footwall gneisses and leucogranites in the Kharta valley, approximately $57 \mathrm{~km}$ due north of Makalu, in Tibet. (h) The STD shear zone on the east flank of the Rongbuk valley. Os are Ordovician sediments above the Qomolangma detachment (QD). Es is the Everest series greenschists between the QD and the Lhotse detachment (LD). Lg are leucogranite sills. 

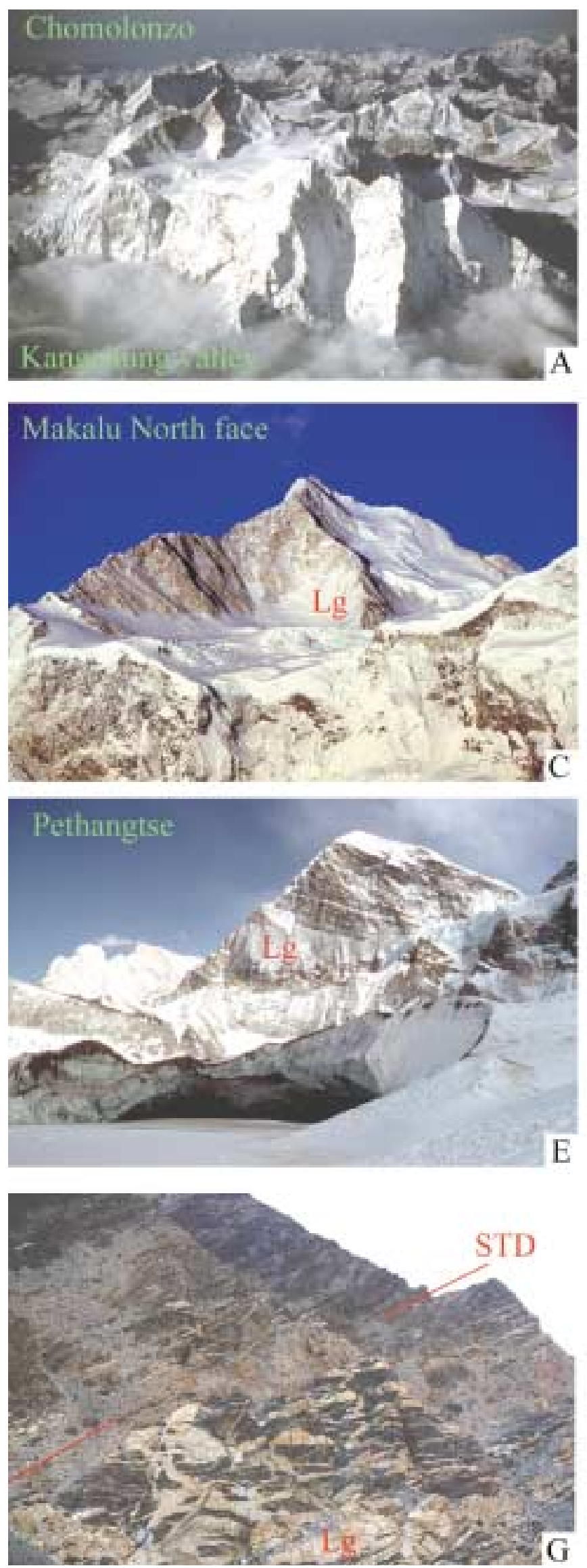
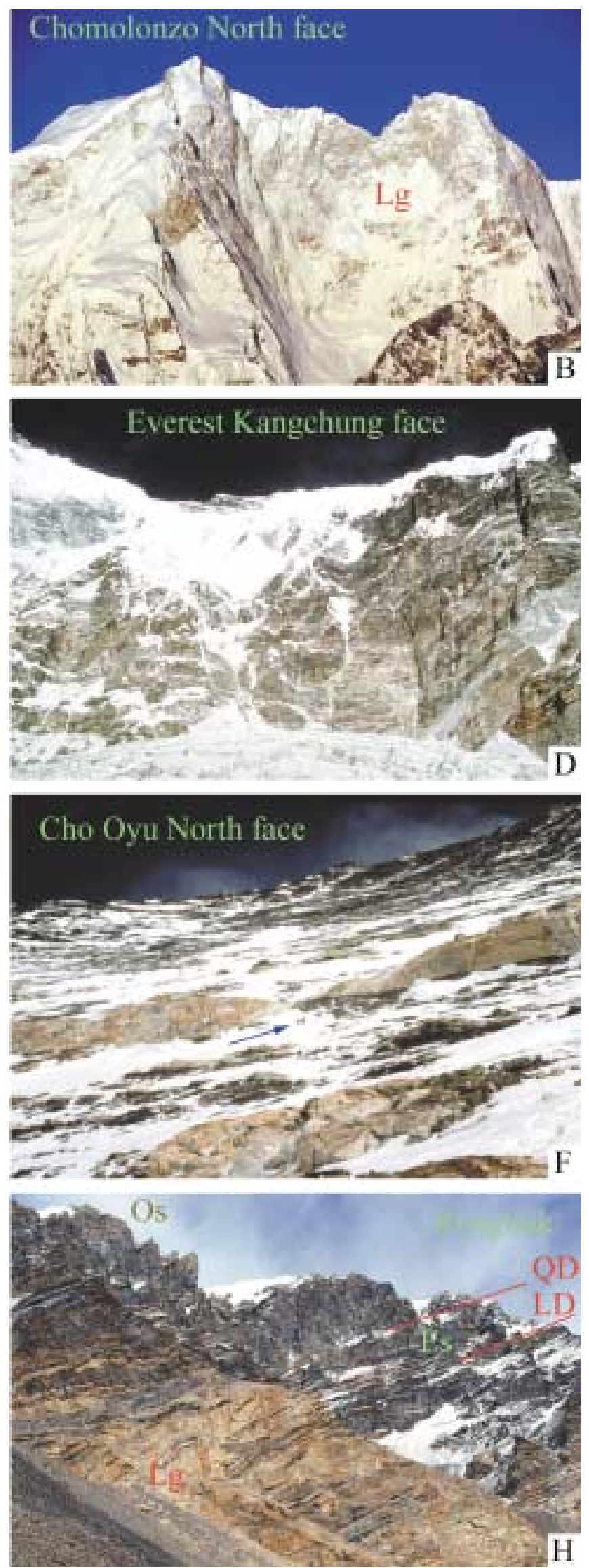
the major zone of high strain associated with Main Central Thrust-related shearing is generally thought to be structurally towards the base of the inverted metamorphic sequence, not within the sillimanite grade zone.

\section{Depth of metamorphism and restoration of the South Tibetan Detachment.}

We have used calculated pressures to constrain depths of metamorphism from the gneiss of the Greater Himalayan slab beneath the South Tibetan Detachment shear zones. Three samples collected from Kala Patar near Everest Base Camp on the Khumbu glacier contain the assemblage: $\mathrm{Grt}+\mathrm{Sil}+\mathrm{Bt}+$ $\mathrm{Pl}+\mathrm{Qtz} \pm \mathrm{Crd}$ and have equilibrium $P-T$ conditions of $623 \pm 79{ }^{\circ} \mathrm{C}, \quad 4.0 \pm 0.8 \mathrm{kbar}, \quad 626 \pm 79{ }^{\circ} \mathrm{C}, 4.1 \pm 0.8 \mathrm{kbar}$ and
$651 \pm 41{ }^{\circ} \mathrm{C}, 4.9 \pm 1.4$ kbar respectively. Independent Grt-Bt and Grt-Crd thermometers yield similar temperatures. Our samples collected from the immediate footwall of the South Tibetan Detachment at Rongbuk monastery are devoid of garnet and therefore unsuitable for obtaining pressure estimates. Twofeldspar thermometry fails to retrieve peak temperatures from these rocks owing to late stage unmixing reducing the albite content of orthoclase. Therefore we use the samples from Kala Patar for our structural restoration of the South Tibetan Detachment, which record peak conditions of $620^{\circ} \mathrm{C}$ at depths of $14-$ $18 \mathrm{~km}$. Nevertheless, the garnet-bearing sample from the Rongbuk valley described by Hodges et al. (1992) gives an identical $P-T$ result of $630{ }^{\circ} \mathrm{C}$ and $4.6 \mathrm{kbar}(16-17 \mathrm{~km})$.

Assuming a conservative constant dip of $10^{\circ}$ of the South Tibetan Detachment north of Rongbuk and a pressure gradient of

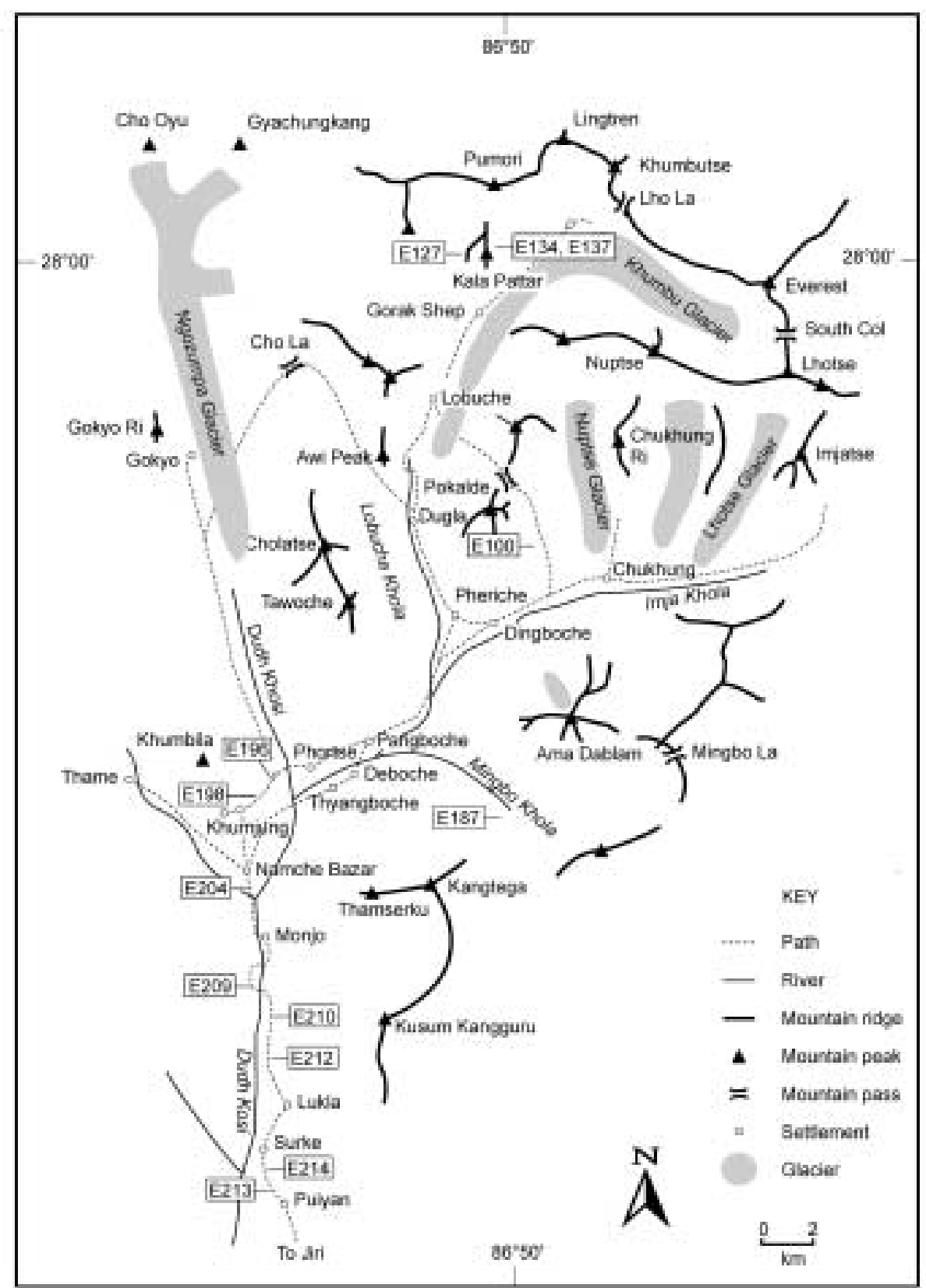

Fig. 8. (a) Map of the Khumbu Himalaya showing localities of samples used for thermobarometry. (b) Profiles of temperature derived from conventional thermometry, and pressure calculated by THERMOCALC, against map distance north of the MCT zone for samples from the Khumbu valley. 
$3.5 \mathrm{~km} \mathrm{kbar}{ }^{-1}$, we obtain horizontal displacements of footwall Greater Himalayan slab rocks $90-108 \mathrm{~km}$ south (Fig. 10). If we use a more realistic $5^{\circ}$ dip, the dip measured along the upper Rongbuk glacier, we obtain horizontal displacements of 180$216 \mathrm{~km}$ south. The low-angle geometry of the restored Everest Rongbuk profile explains why the temperature is so uniform across the $45 \mathrm{~km}$ wide zone of the sillimanite gneisses south of Everest. This is compatible with the sillimanite gneisses of the Greater Himalayan slab being extruded from mid-crustal levels at $14-18 \mathrm{~km}$ depth beneath the southern part of the Tibetan plateau.

\section{Geochronology}

$\mathrm{U}-\mathrm{Th}-\mathrm{Pb}$ and ${ }^{40} \mathrm{Ar} /{ }^{39} \mathrm{Ar}$ geochronological data from the Everest area and Rongbuk glacier are summarized on Figure 11. Simpson et al. (2000) obtained a U-Pb monazite age of $32.2 \pm 0.4 \mathrm{Ma}$ from a metapelitic gneiss containing the assemblage $\mathrm{Grt}+\mathrm{Bt}+$ $\mathrm{Sil}+\mathrm{Crd}+\mathrm{Ky}+\mathrm{Qtz}+\mathrm{Pl}+\mathrm{Kfs}$ from Kala Patar peak at the head of the Khumbu glacier in Nepal. This age is interpreted as the timing of peak Barrovian metamorphism. These authors also obtained a $\mathrm{U}-\mathrm{Pb}$ monazite age from a granitic augen gneiss, also from Kala Patar, with the assemblage: $\mathrm{Kfs}+\mathrm{Pl}+\mathrm{Bt}+\mathrm{Sil}+$
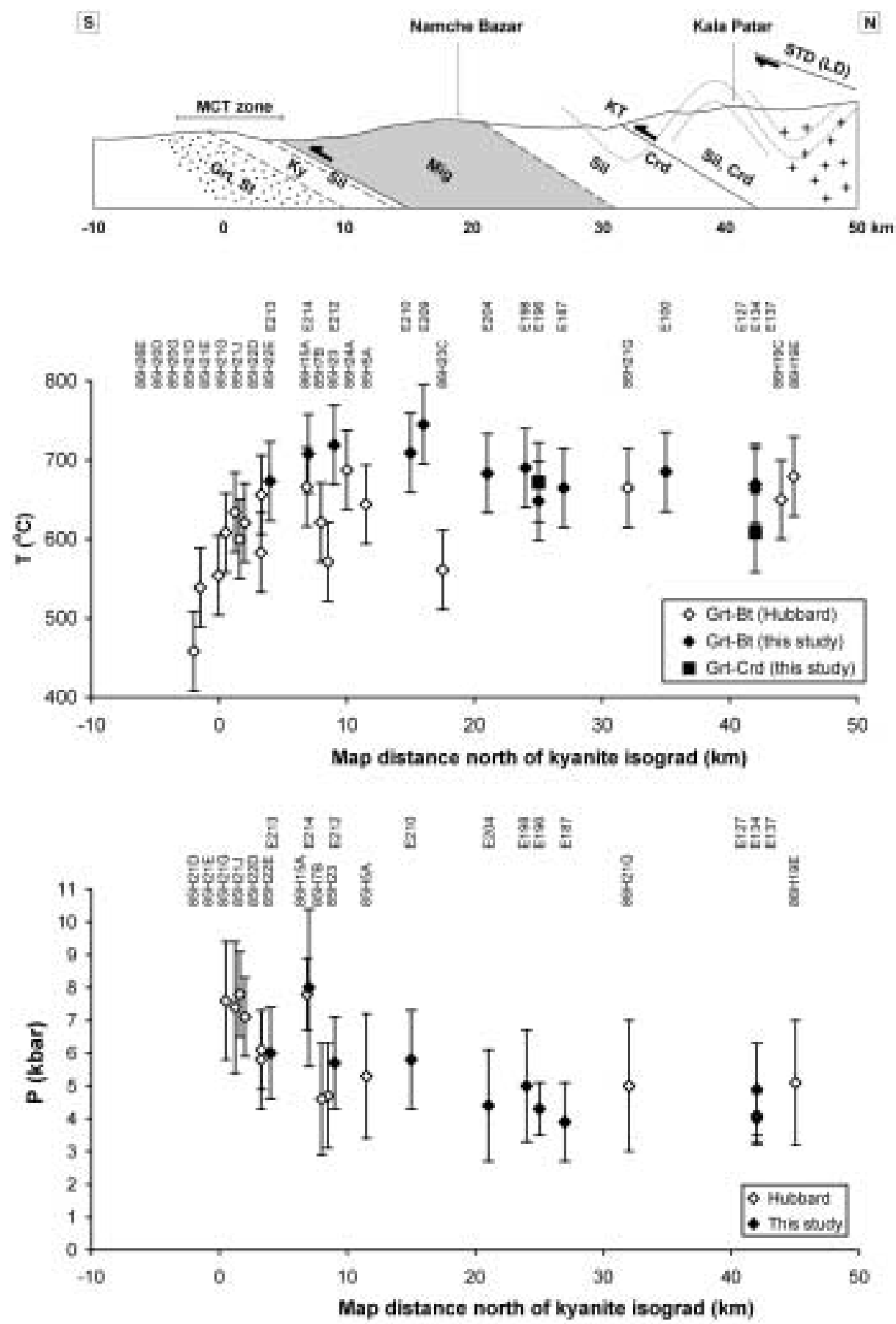

Fig. 8. (continued) 
Table 1. T results for Everest area samples

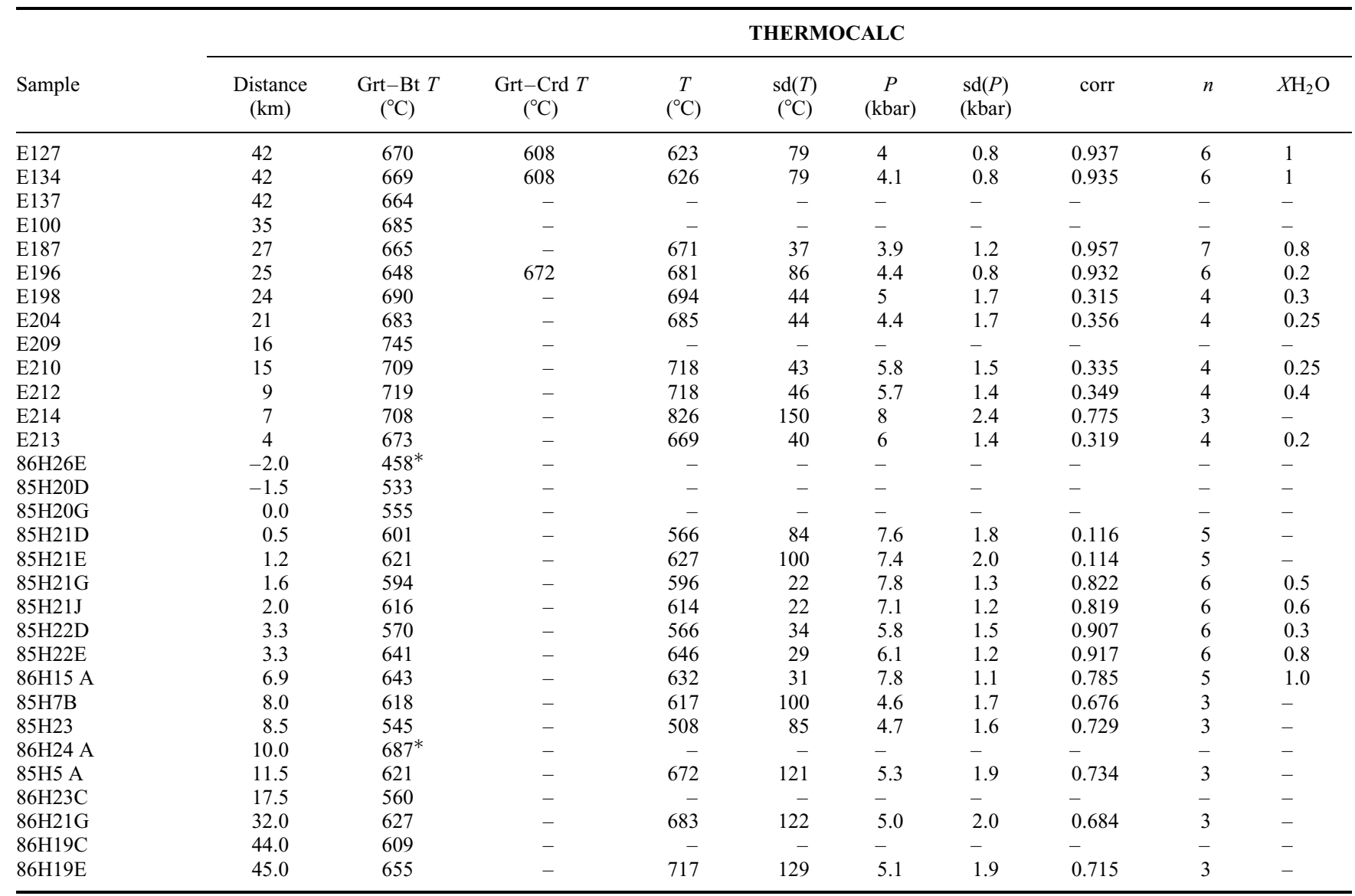

Distances are measured from the mapped position of the kyanite isograd.

Garnet-biotite exchange temperatures were calculated using the calibration 5AV of Holdaway (2000).

Garnet-cordierite exchange temperatures are calculated with the calibration of Perchuk and Lavrent'eva (1983).

Corr is the correlation between the standard deviations on $P$ and on $T ; n$ is the number of independent reactions.

${ }^{*}$ In the absence of a full analysis for biotite, $T$ calculated with thermometer of Bhattacharya et al. (1992; HW calibration).

$\mathrm{Crd}+\mathrm{Ms}$ of $22.7 \pm 0.2 \mathrm{Ma}$. This is interpreted as the age of a later, high-temperature low-pressure event $\left(\right.$ c. $\left.620^{\circ} \mathrm{C}, 4 \mathrm{kbar}\right)$. The Everest leucogranites contain biotite, muscovite and tourmaline, and a sample collected from above Base Camp on the Khumbu glacier gave $\mathrm{U}-\mathrm{Pb}$ monazite and xenotime ages spanning 20.5-21.3 Ma (Simpson et al. 2000). Along the Rongbuk glacier, north of Everest, two sets of leucogranite sills and dykes occur in the cliff section above Rongbuk monastery. An earlier set of sills (set 1) are foliation parallel and contain a deformation fabric which is parallel to the enclosing gneisses, whilst a later set of dykes (set 2) cross-cut the ductile fabrics in the gneisses, but are in turn truncated by the brittle fault at the top of the South Tibetan Detachment zone of high strain (Fig. 11). Murphy \& Harrison (1999) published $\mathrm{Th}-\mathrm{Pb}$ monazite ages of $16.2 \pm 0.8 \mathrm{Ma}$ for the earlier set of deformed sills, and $16.40 \pm 0.6 \mathrm{Ma}$ and $16.80 \pm 0.8 \mathrm{Ma}$ for the later set of crosscutting dykes. These later ages agree closely with ${ }^{40} \mathrm{Ar} /{ }^{39} \mathrm{Ar}$ age $16.37 \pm 0.4 \mathrm{Ma}$ obtained by Hodges et al. (1998). The age of ductile shearing is therefore constrained very precisely at c. $17 \mathrm{Ma}$, prior to the late cross-cutting dykes, whilst the age of brittle faulting along the top of the South Tibetan Detachment shear zone must be younger than $16 \mathrm{Ma}$.

Sample E11 collected from a set 2 dyke outcrop on Lingtren (Fig. 6c) was devoid of datable accessory minerals with the exception of one xenotime crystal which produced a slightly reversely discordant analysis with a ${ }^{207} \mathrm{~Pb} /{ }^{235} \mathrm{U}$ age of $16.4 \pm 0.1 \mathrm{Ma}$ and $\mathrm{a}{ }^{206} \mathrm{~Pb} /{ }^{238} \mathrm{U}$ age of $16.6 \pm 0.1 \mathrm{Ma}$ and $\mathrm{a}$ ${ }^{206} \mathrm{~Pb} /{ }^{238} \mathrm{U}$ age of $16.6 \pm 0.1 \mathrm{Ma}$ (Fig. 12). We interpret c. $16.5 \mathrm{Ma}$ as the age of this dyke and a minimum age for the ductile fabric in the sillimanite gneiss that it truncates. A similar cross-cutting garnet + tourmaline + muscovite leucogranite dyke (sample E62) from the south face of Lhotse (Fig. 6e) yielded two monazite fractions, one reversely discordant with a ${ }^{207} \mathrm{~Pb} /{ }^{235} \mathrm{U}$ age of $20.2 \pm 1.0 \mathrm{Ma}$ and the other containing a signature of inherited monazite of probable early Palaeozoic age.

Sample E282 was collected from outcrop located just east of Everest base camp in the Rongbuk valley adjacent to the Hermit's gorge (Fig. 3). It is a finely foliated Qtz $+\mathrm{Pl}+\mathrm{Mc}+$ Bt schist, devoid of an Al-silicate phase. It contained very small quantities of rather fine-grained monazite, although sufficient quantities were recovered to analyse three multi-grain fractions (Fig. 12) by both $\mathrm{U}-\mathrm{Th}$ and $\mathrm{Th}-\mathrm{Pb}$ methods (Table 2). Two fractions (M-1 and M-3) plot concordantly at $16.9 \pm 0.1 \mathrm{Ma}$, have similar ${ }^{208} \mathrm{~Pb} /{ }^{232} \mathrm{Th}$ ages $(16.6-16.9 \mathrm{Ma})$ and low $\mathrm{Th} / \mathrm{U}$ ratios, consistent with a lack of significant reverse discordance. The third fraction $\mathrm{M}-2$ is normally discordant in the $\mathrm{U}-\mathrm{Pb}$ system and contains evidence of a small amount of monazite inheritance. ${ }^{208} \mathrm{~Pb} /{ }^{232} \mathrm{Th}$ ages of mineral aliquots $\mathrm{M}-1$ and $\mathrm{M}-3$ closely agree with the $\mathrm{U}-\mathrm{Pb}$ ages at $16.9 \mathrm{Ma}$. The ${ }^{208} \mathrm{~Pb} /{ }^{232} \mathrm{Th}$ age of the $\mathrm{U}-\mathrm{Pb}$ discordant fraction $\mathrm{M}-2$ is the oldest at 

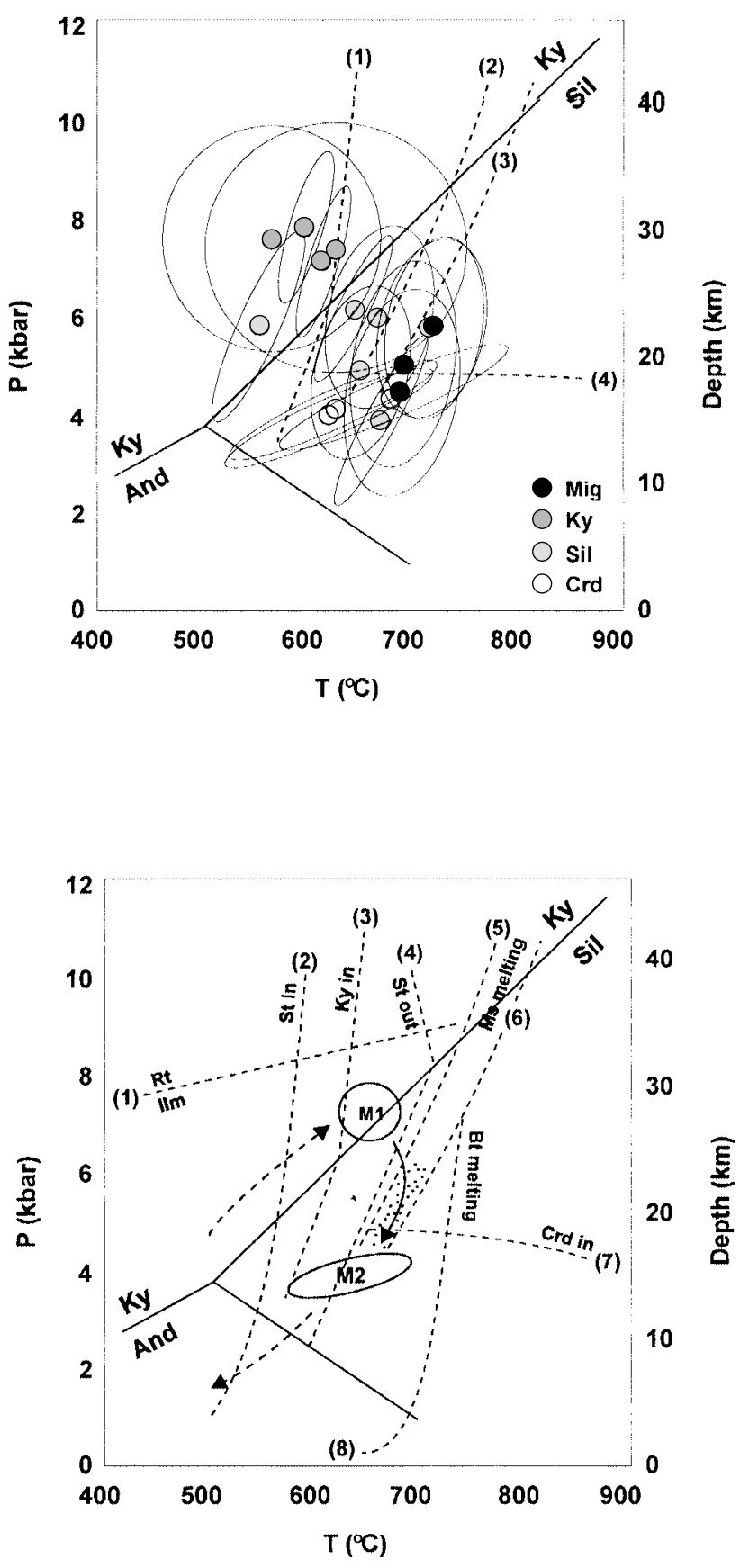

Fig. 9. (a) Summary of selected THERMOCALC $P-T$ results from the Khumbu valley samples. See Figure 8 a for location of all samples. Reactions: (1) $\mathrm{St}+\mathrm{Chl}=\mathrm{Bt}+\mathrm{As}+\mathrm{V}$ (from Spear 1993); (2) Ms + $\mathrm{Ab}+\mathrm{Qtz}=\mathrm{Kfs}+\mathrm{As}+\mathrm{Melt} ;(3) \mathrm{Ms}+\mathrm{An}+\mathrm{Qtz}=\mathrm{Kfs}+\mathrm{Ab}+$ Melt (from Le Breton \& Thompson 1988); (4) Alm + Sil + Qtz + V = FeCrd (for $\mathrm{CrdX}_{\mathrm{Fe}}=0.6$; from Mukhopadhyay \& Holdaway 1994). (b) $P-T$ path for the mid to upper Greater Himalayan slab crystallines at Everest inferred from phase equilibria and thermobarometry. Reactions: (1) Alm $+\mathrm{Rt}=\mathrm{Ilm}+\mathrm{Ky}+\mathrm{Qtz}$ (from Bohlen et al. 1983); (2) Grt $+\mathrm{Chl}=\mathrm{St}$ $+\mathrm{Bt}+\mathrm{V}$; (3) $\mathrm{St}+\mathrm{Chl}=\mathrm{Bt}+\mathrm{Ky}+\mathrm{V}$; (4) $\mathrm{St}=\mathrm{Grt}+\mathrm{Bt}+\mathrm{As}+\mathrm{V}$ (from Spear 1993); (5) Ms $+\mathrm{Ab}+\mathrm{Qtz}=\mathrm{Kfs}+\mathrm{As}+\mathrm{Melt} ;(6) \mathrm{Ms}+$ $\mathrm{An}+\mathrm{Qtz}=\mathrm{Kfs}+\mathrm{Ab}+$ Melt (from Le Breton \& Thompson 1988); (7) $\mathrm{Alm}+\mathrm{Sil}+\mathrm{Qtz}+\mathrm{V}=\mathrm{FeCrd}$ (for $\mathrm{CrdX}_{\mathrm{Fe}}=0.6$; from Mukhopadhyay \& Holdaway 1994); (8) Bt + Als $+\mathrm{Pl}+\mathrm{Qtz}=\mathrm{Grt}+\mathrm{Kfs}+$ Melt (from Le Breton \& Thompson 1988). M1 and M2 refer to the two metamorphic episodes dated in the Everest region.
$18.3 \pm 0.2 \mathrm{Ma}$, which supports the inheritance interpretation. We suggest that it is reasonable to interpret the crystallization age the metamorphic monazite in the sample to be $16.9 \pm 0.2 \mathrm{Ma}$, the weighted mean age of the ${ }^{206} \mathrm{~Pb} /{ }^{238} \mathrm{U},{ }^{207} \mathrm{~Pb} /{ }^{235} \mathrm{U}$ and ${ }^{208} \mathrm{~Pb} /$ ${ }^{232} \mathrm{Th}$ data for fractions M-1 and M-3.

Because Murphy \& Harrison (1999) concluded that $16.4 \pm 0.6$ Ma leucogranite dykes are sheared into parallelism with the foliation, the ductile strain associated with the detachment fault was active at approximately $17 \mathrm{Ma}$. It seems sensible to conclude that the formation of monazite in sample E282 at $16.9 \pm 0.2 \mathrm{Ma}$ is associated either with the culmination of sillimanite-grade metamorphic conditions, or with the extensional movement on the fault. Hodges et al. (1992) present data suggesting that rocks from a similar structural position to E278 and E282 experienced amphibolite facies conditions at 20-21 Ma. The age of $16.9 \pm 0.2 \mathrm{Ma}$ from sample E282 is not consistent with their conclusion, unless that event was protracted. Plastic recrystallization textures in sample E282 indicate that deformation occurred at around $600{ }^{\circ} \mathrm{C}$, conditions at which monazite growth is possible (Smith \& Barriero 1990), particularly if crystallization were assisted by increased fluid flux along the fault above, in a similar scenario to that proposed by Simpson et al. (2000). We conclude that our age of E282 on the strongly sheared schists dates the ductile extensional motion along the South Tibetan Detachment at Rongbuk. Brittle motion along the South Tibetan Detachment must be younger than the leucogranite dykes in the footwall, dated at around 16.5 Ma (Murphy \& Harrison, 1999).

Figure 13 shows a summary of all the key events in the Greater Himalayan slab in the Everest region, and Figure 14 plots the geochronological data on a temperature-time chart. We now use these data to constrain a model for the tectonic evolution of the central Nepal-south Tibet Himalaya along the Everest transect.

\section{Tectonic evolution}

The age of India-Asia collision is fairly well constrained at around $50 \mathrm{Ma}$ from the youngest marine sediments within the Indus Tsangpo suture zone and along the northern continental margin of the Indian plate (P7 planktonic foraminiferal zone of the early Eocene; Rowley 1996, 1998). Following collision, the Indian plate margin began to shorten and thicken across the Tethyan margin north of the South Tibetan Detachment. Peak burial metamorphism occurred at c. $32 \mathrm{Ma}$ during the Oligocene (Simpson et al. 2000), and temperatures remained high for some 14 million years from 32 to $17 \mathrm{Ma}$ during which sillimanite \pm cordierite metamorphism was occurring across the Greater Himalayan slab at pressures of 4-5 kbar and depths of 13$17 \mathrm{~km}$. Partial melting of the Namche migmatites occurred at 25-22 Ma (Viskupic \& Hodges 2001) and large-scale melting of the Everest leucogranites occurred at 21.3-20.5 Ma (Simpson et al. 2000). Along the top of the Greater Himalayan slab, ductile shearing during sillimanite grade metamorphism lasted until $17 \mathrm{Ma}$, after which the last leucogranite dykes were intruded at 16.8-16.5 Ma (Murphy \& Harrison 1999). As the Greater Himalayan slab was being exhumed during south-directed ductile flow, erosion rates increased dramatically during decompression. At $16 \mathrm{Ma}$ brittle down-to-north faulting occurred along the South Tibetan Detachment (Qomolangma detachment) truncating all metamorphic rocks and leucogranites in the footwall. The temperature-time plot (Fig. 14) demonstrates that rapid cooling during the transition from high-temperature ductile shearing to low-temperature brittle faulting along the South Tibetan Detachment immediately followed widespread crustal melting along the 


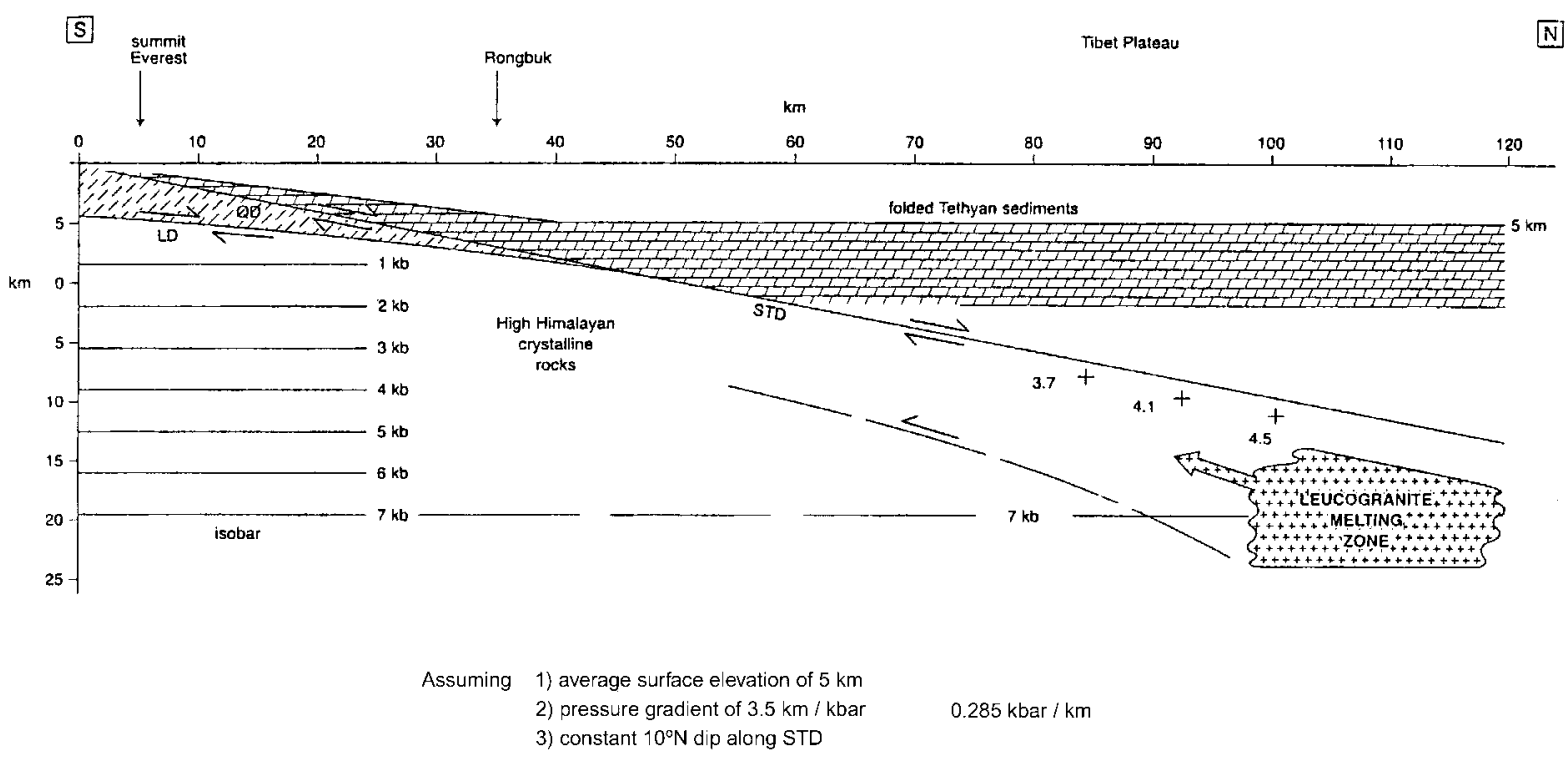

Fig. 10. Restoration of the Everest profile (Fig. 4a). The upper Qomolangma detachment (QD) and lower Lhotse detachment (LD) are both faults of the South Tibetan detachment system series of low-angle normal faults. Crosses mark the restored positions and depth of three samples from Kala Patar, $2 \mathrm{~km}$ SW of Everest, which record pressures of 3.7, 4.1 and $4.5 \mathrm{kbar}$. Using an average $10^{\circ}$ dip of the STD the relative southward displacement of the sillimanite grade rocks along the footwall is $90-108 \mathrm{~km}$. The true dip of the STD as measured on the north face of Everest and along the Rongbuk glacier is between $3-5^{\circ} \mathrm{N}$; at this angle the relative displacement along the STD would be $180-216 \mathrm{~km}$. The approximate depth and original position of the Everest leucogranites prior to emplacement along the footwall of the STD is also shown.

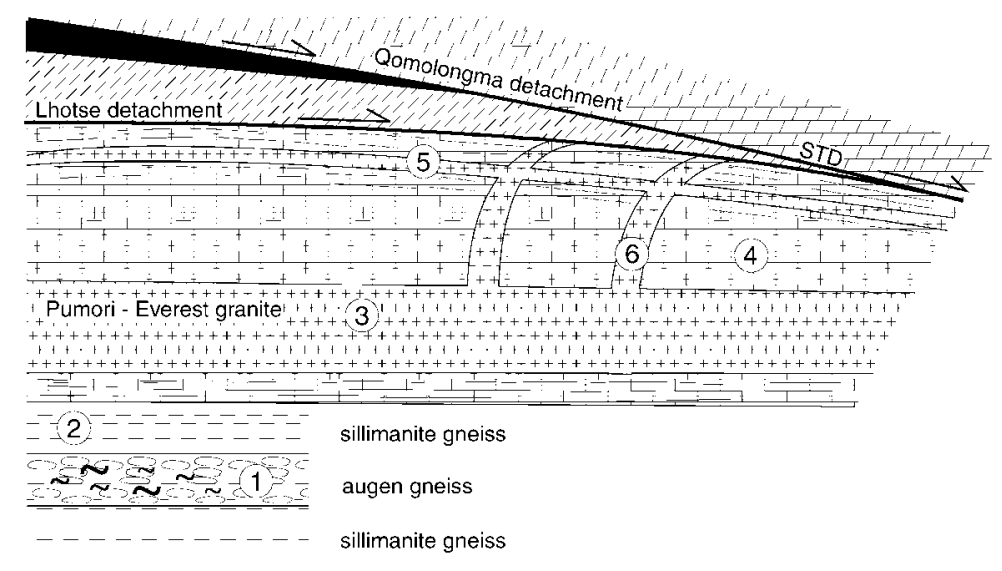

Brittle faulting STD

(6) Underformed cross-cutting dykes

Ductile shearing STD

(5) Deformed leucogranite sills

(4) Fault-associated or contact metamorphism, Rongbuk

(3) Melting Everest granite

(2) Low-P cordierite metamorphism (M2)

(1) -Max-P metamorphism (M1)
Ma

$<16$

$\begin{array}{lll}\left\{\begin{array}{lll}16.37 \pm 0.4 & \mathrm{Ar} / \mathrm{Ar} & \mathrm{H} \text { et al. } \\ 16.40 \pm 0.6 & \mathrm{Th} / \mathrm{Pb} & \mathrm{M} \& \mathrm{H} \\ 16.80 \pm 0.8 & \mathrm{Th} / \mathrm{Pb} & \mathrm{M} \& \mathrm{H}\end{array}\right. \\ \sim 17 & & \\ 16.2 \pm 0.8 & \mathrm{Th} / \mathrm{Pb} & \mathrm{M} \& \mathrm{H} \\ 16.67 \pm 0.04 & \mathrm{U}-\mathrm{Pb} & \mathrm{H} \text { et al. } \\ 17.9 \pm 0.5 & \mathrm{U}-\mathrm{Pb} & S \text { data } \\ 20.5-21.3 & \mathrm{U}-\mathrm{Pb} & S \text { et al. } \\ 22.7 \pm 0.2 & \mathrm{U}-\mathrm{Pb} & S \text { et al. } \\ 32.2 \pm 0.4 & \mathrm{U}-\mathrm{Pb} & S \text { et al. }\end{array}$

Fig. 11. Summary of the structural relationships at Rongbuk with $\mathrm{U}-\mathrm{Th}-\mathrm{Pb}$ and ${ }^{40} \mathrm{Ar} /{ }^{39} \mathrm{Ar}$ ages from Hodges et al. (1998; H et al.); Murphy \& Harrison (1999; M\&H); Simpson et al. (2000; S et al.) 
top of the Greater Himalayan slab. Melt-enhanced deformation may have been responsible for increased extrusion rates during this time. By the time brittle faulting took over along the South Tibetan Detachment, metamorphism and melting were over and the entire Greater Himalayan slab had cooled to below the muscovite closing temperature in the $\operatorname{Ar}$ system $\left(350{ }^{\circ} \mathrm{C}\right)$. The period from 16-2.5 Ma was marked by slow cooling at c. 20$22.5^{\circ} \mathrm{C} \mathrm{Ma}^{-1}$. with exhumation rates $0.2-2 \mathrm{~mm} \mathrm{a}^{-1}$ assuming a $25-35^{\circ} \mathrm{C} \mathrm{km}^{-1}$ gradient. A final phase of rapid exhumation and erosion at less than c. 2.5 Ma must have been controlled by the onset of the Quaternary glaciation and enhanced climate-driven erosion.

Our field, structural and chronological data supports the contention that, between 21-16 Ma. a mid-crustal layer was at high temperature, was deforming in a ductile manner with a combination of both pure shear and simple shear (Law et al. in prep.), and was partially melting in situ to produce leucogranite sheets, which migrated horizontally following planes of anisotropy defined by the metamorphic foliation. Widespread melting producing the Everest-Rongbuk leucogranites triggered both rapid uplift and cooling of the Greater Himalayan slab rocks (exhumation) and ductile extrusion of this low-viscosity, midcrustal layer along the Himalaya. This channel was bounded by a flattened and sheared ductile shear zone at the base (Main Central Thrust zone) with inverted metamorphism, and a ductile shear zone at the top (Lhotse detachment), which was later cut by brittle faults $<16 \mathrm{Ma}$ ago, as the whole Greater Himalayan metamorphic slab was exhumed, cooled and 'frozen in'. The uniform high temperatures and low pressures across the middle part of the Greater Himalayan slab support the model of channel flow and ductile extrusion (Nelson et al. 1996; Vannay \& Grasemann 2001, Beaumont et al. 2001; Hodges et al. 2001; Grujic et al. 2002).

\section{Conclusions}

Lithospheric convergence of India and Asia since collision at c. $50 \mathrm{Ma}$. has resulted in horizontal shortening, crustal thickening and regional metamorphism in the Himalaya and beneath southern Tibet. India and Asia have always been in relative convergence and the current shortening rates across the Himalaya are

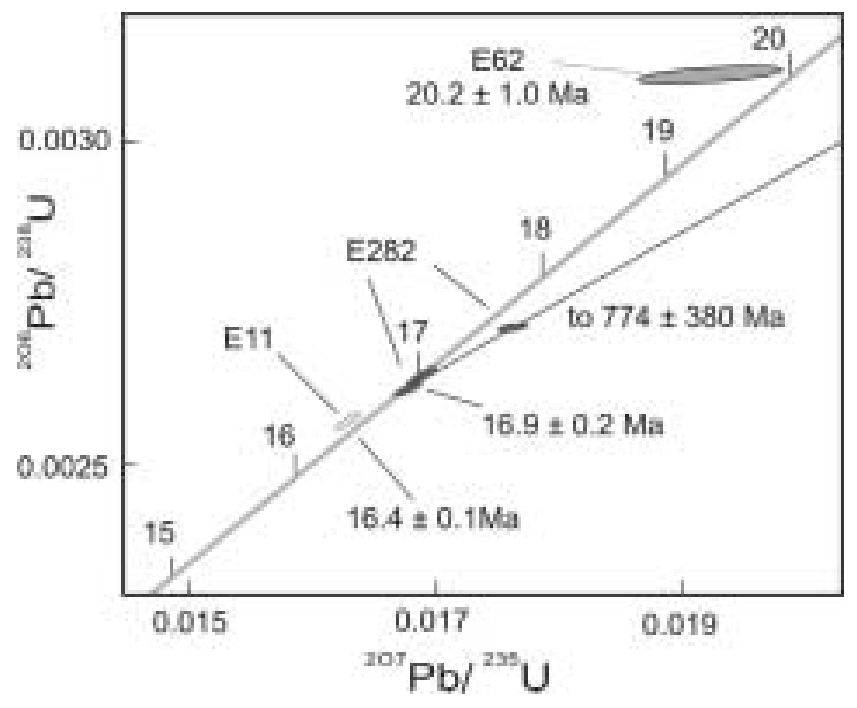

Fig. 12. U-Pb Concordia diagram for samples E62, E11 and E282. E11 is a xenotime age; others are all monazites.

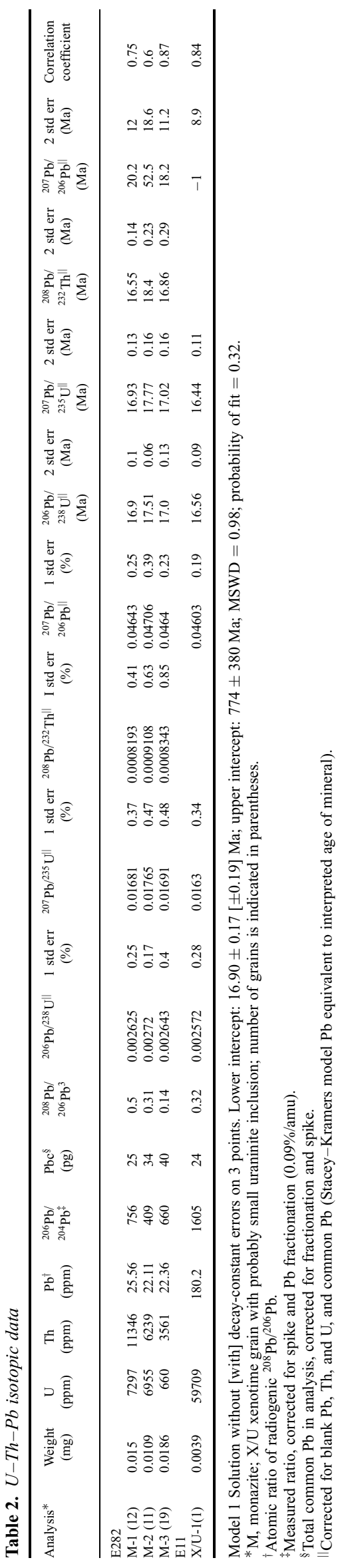




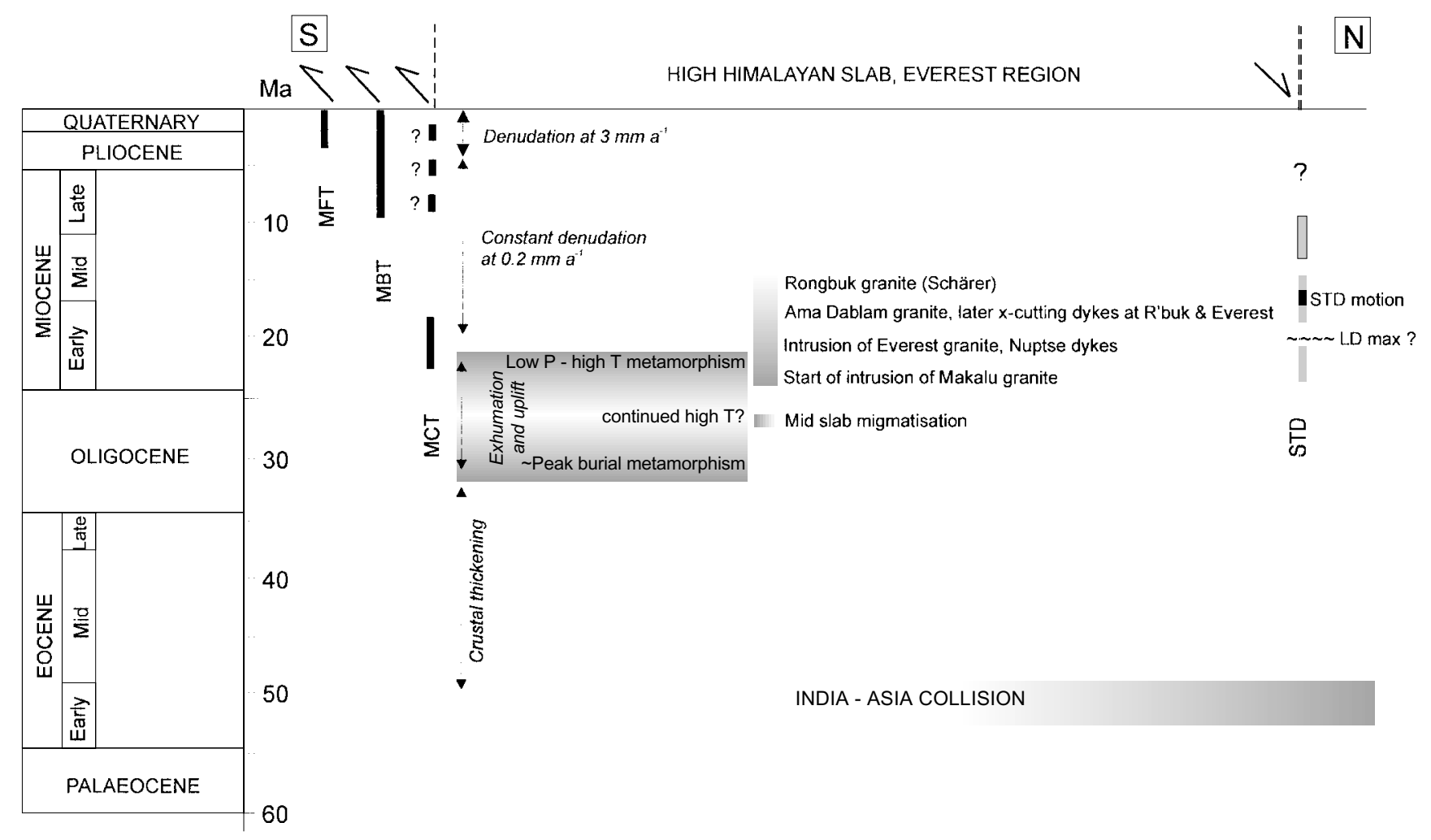

Fig. 13. Time chart summarizing the main events in the Everest Himalaya; see text for sources of data and discussion.

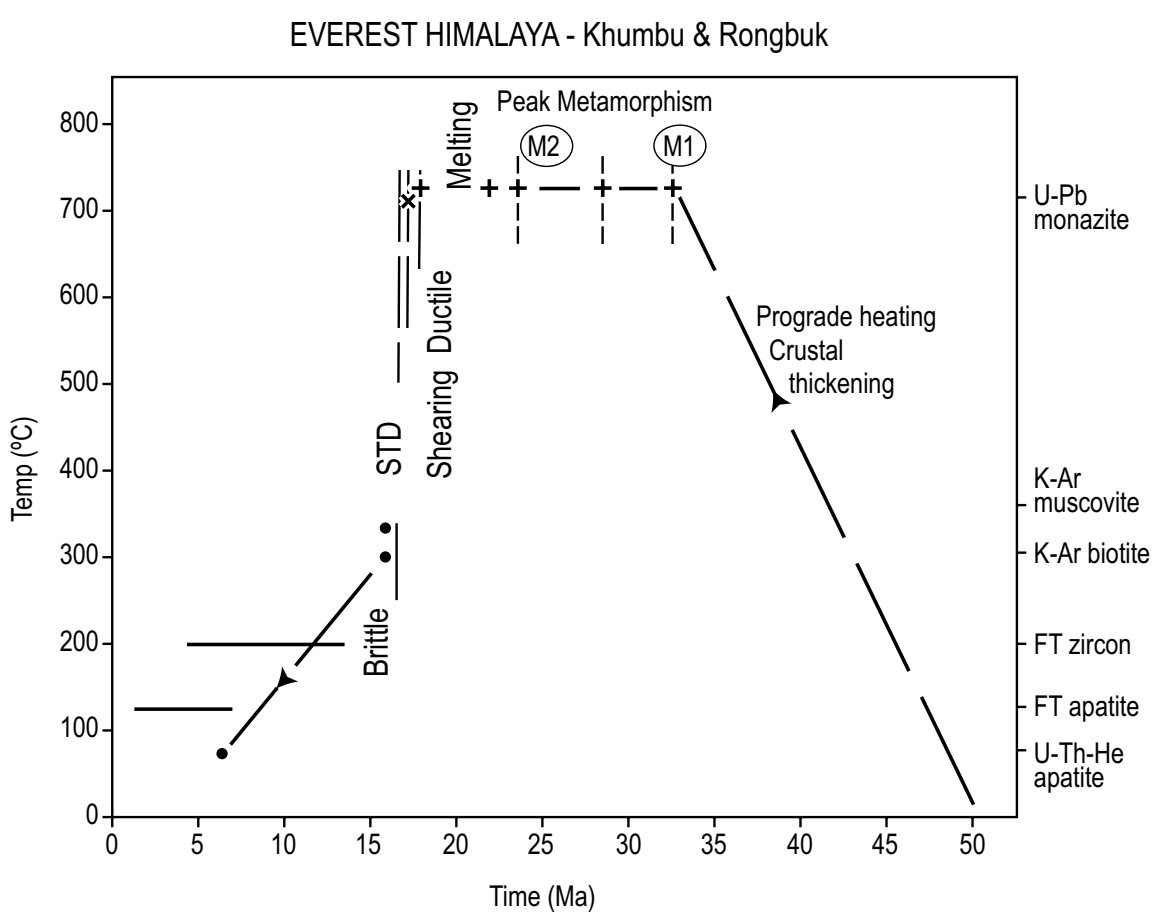

Fig. 14. Temperature-time diagram showing the age data for the Everest Himalaya in Nepal and south Tibet with a summary of the dominant tectonic processes. Mineral closure temperatures are shown on the right. Monazite temperatures are interpreted as growth ages according to individual magmatic or metamorphic $(P-T)$ conditions. Geochronology data is from Bergman et al. (1993), Hubbard \& Harrison (1989), Hodges et al. (1998), Murphy \& Harrison (1999), Hubbard \& House (2000), Simpson et al. (2000) and this paper.
17-18 $\mathrm{mm} \mathrm{a}^{-1}$ (Bilham et al. 1997). Earlier interpretations of South Tibetan Detachment structures in the Himalaya include gravitational collapse of the Miocene topographic front (Burchfiel \& Royden 1985) and alternating periods of north- south extension and north-south compression (Hodges et al. 1996, 2001; Vannay \& Hodges 1996). The gravitational collapse model is inappropriate because collapse implies a lowering of surface elevation, which has not happened in the Himalaya or 
south Tibet. Indeed it is quite possible than surface elevation increased during active normal faulting along the South Tibetan Detachment, by underthrusting of material at lower levels of the Greater Himalayan slab along the proto-Main Central Thrust zone. It is not appropriate that the age of initiation of normal faults (either east-west South Tibetan Detachment type faults, or north-south aligned normal faults in south Tibet) should be a proxy for the age of maximum elevation of the Tibetan plateau. From the structural and geochronological evidence, we believe that southward shearing along the Main Central Thrust zone was occurring simultaneously with north-directed normal faulting along the South Tibetan Detachment zone. However, no net extension occurred across the South Tibetan Detachment, which is a 'stretching fault' (Means 1989) in a purely compressive environment. The hanging-wall rocks remained fixed while the footwall rocks were extruded southwards beneath the South Tibetan Detachment. Some kind of channel flow mechanism must have been operative, feeding material in by underthrusting from the south along the Main Central Thrust-related shear zones, and extruding it south at higher structural levels along the footwall of the South Tibetan Detachment shear zones at the top the Greater Himalayan slab channel (Beaumont et al. 2001).

Our studies of the Everest region suggest that the South Tibetan Detachment shear zones and normal faults propagated upwards, away from the centre of the Greater Himalayan slab channel, and were broadly contemporaneous with timing of motion along the Main Central Thrust (Hubbard \& Harrison 1989). The lower Lhotse Detachment was active between 18 and $16 \mathrm{Ma}$ while the upper Qomolangma Detachment was active at less than $16 \mathrm{Ma}$ ago. Along the base of the channel, we suggest that the Main Central Thrust propagated southwards and structurally downwards with time. Early Miocene motion occurred along the kyanite grade gneisses and the younger shearing along the structurally lower garnet-biotite grade rocks. Thus the southward extruding channel of the Greater Himalayan slab was probably growing outward with time. The biggest puzzle is why this extrusion process apparently stopped at around $16 \mathrm{Ma}$ when muscovite $\mathrm{Ar}-\mathrm{Ar}$ ages indicate that the entire slab cooled through $350{ }^{\circ} \mathrm{C}$. Although it has been argued that abrupt physiographic transitions across the Main Central Thrust and the South Tibetan Detachment suggest that these structures may be neotectonically active (Hurtado et al. 2001; Hodges et al. 2001), there is no seismological evidence for this current activity. In the Dhaulagiri-Annapurna-Manaslu region of west Nepal, the actual major physiographic boundary between the Himalaya and Tibetan plateau does not coincide with the trace of the South Tibetan Detachment, which crops out south of the main watershed range. The reason for this physiological divide along both the Main Central Thrust and South Tibetan Detachment is more likely due to sub-surface ramping along the Main Himalayan fault, which is seismically active and carries the entire orogen southward over the Siwalik molasse basin (Cattin \& Avouac 2000).

We conclude that the large-scale morphology, structure and thermal evolution of the Everest Himalaya and south Tibetan plateau reflects ductile flow of a mid-crustal channel which was actively extruding southward from underneath the southern part of the Tibetan plateau. Rocks in the core of the channel are HT sillimanite-grade gneisses, migmatites and crustal melt leucogranites, which were extruded southwards between the Main Central Thrust and South Tibetan Detachment ductile shear zones and subjected to rapid erosion along the active Himalayan front, during the early Miocene. Major thrust-sense shear zones along the base and normal sense shear zones along the top of this channel expanded outwards with time, but both ductile shear zones and active extrusion were effectively over by $16 \mathrm{Ma}$, by which time the entire Greater Himalayan slab had cooled below the muscovite closing temperature $\left(\right.$ c. $\left.350^{\circ} \mathrm{C}\right)$. After this, the entire Greater Himalayan slab was carried piggy-back, and uplifted, by younger thrusts developing in the Lesser Himalaya and Main Boundary thrust system to the south.

This work was funded by a NERC grant (NER/K/S/2000/951) to M.P.S., a NERC post-graduate studentship to R.L.S., and an NSF grant (EAR 0207524) to R.L.D. and M.P.S. We thank the Tectonic Studies Group in UK and the Geological Society of London for contributions towards the cost of colour printing. We are grateful to Bradford Washburn (Boston Museum of Science) and Erich Keller (Swissphotos) for aerial photographs, René Schrama, Shiva Dhaktal, Tasi Sherpa and Manoj Kumar Rai for logistical help in Nepal and Tibet, and Jon Tinker and Russell Brice for use of their base camps on the Khumbu and Rongbuk sides of Everest. We thank Grahame Oliver for illite crystallinity data, Ian Brewer, Nick Groves and Paul Harris for field assistance and Stephen Venables, Marko Prezelj and David Spencer for use of their photos on Everest's Kangchung face, Gyachung Kang and Cho Oyu respectively. We are particularly grateful to Leo Dickinson for his spectacular photos of the Everest massif taken from his epic hot air balloon ride across the mountain. Special thanks also to Richard McAvoy for digital imaging, Natalie Portelance for digitization of the base map and Dave Sansom for expert drafting. Finally, we thank the reviewers, Rebecca Jamieson, Chris Beaumont and Kip Hodges for detailed reviews, and the editor Rob Strachan for his support.

\section{References}

Alsdorf, D. \& Nelson, K.D. 1999. Tibetan satellite magnetic low: Evidence for widespread melt in the Tibetan crust? Geology, 27, 943-946.

Alsdorf, D., Brown, L., Nelson, K.D., Makovsky, Y., Klemperer, S. \& Zhao, W. 1998. Crustal deformation of the Lhasa terrane from Project INDEPTH deep seismic reflection profiles. Tectonics, 17, 501-519.

Beaumont, C., Jamieson, R.A., Nguyen, M.H. \& Lee, B. 2001. Himalayan tectonics explained by extrusion of a low-viscosity crustal channel coupled to focused surface denudation. Nature, 414, 738-742.

Bergman, S.C., Coffield, D.Q., Donelick, R., Corrigan, J., Talbot, J., Cerveny, P. \& Kelley, S. 1993. Late Cenozoic compressional and extensional cooling and exhumation of the Qomolangma (Mt Everest) region, Nepal. Geological Society of America Abstracts with Programs, 25(6), A-176.

Bhattacharya, A., Mohanty, L., Maji, A., Sen, S.K.. \& Raith, M. 1992. Nonideal mixing in the phlogopite-annite binary: constraints from experimental data on $\mathrm{Mg}$-Fe partitioning and a reformulation of the biotite-garnet geothermometer. Contributions to Mineralogy and Petrology, 111, 87-93.

Bilham, R., Larson, K., Freymueller, J. \& Project Idylhim Members 1997. GPS measurements of present day convergence across the Nepal Himalaya. Nature, 386, 61-64.

Bohlen, S.R., Wall, V.J. \& Boettcher, A.L. 1983. Experimental investigations and geological applications of equilibria in the system $\mathrm{FeO}-\mathrm{TiO}_{2}-\mathrm{Al}_{2} \mathrm{O}_{3}$ $\mathrm{SiO}_{2}-\mathrm{H}_{2} \mathrm{O}$. American Mineralogist, 68, 1049-1058.

BurchFiel, B.C. \& Royden, L.H. 1985. North-south extension within the convergent Himalayan region. Geology, 13, 679-682.

Burchfiel, B.C., Zhiliang, C., Hodges, K.V., Yuping, L., Royden, L., Changrong, D. \& Jiene, X. 1992. The South Tibetan Detachment System, Himalayan Orogen: extension contemporaneous with and parallel to shortening in a collisional mountain belt. Geological Society of America Special Papers, 269.

Burg, J-P. 1983. Carte Geologique du Sud du Tibet. Ministry of Geology, Peking, and CNRS, Paris.

Burg, J.P., Brunel, M., Gapais, D., Chen, G.M. \& LiU, G.H. 1984. Deformation of leucogranites of the crystalline Main Central thrust sheet in southern Tibet (China). Journal of Structural Geology, 6, 535-542.

BurkHARD, M. 1993. Calcite twins, their geometry, appearance and significance as stress-strain markers and indicators of tectonic regime. Journal of Structural Geology, 15, 351-368.

Carosi, R., Lombardo, B., Molli, G., Musumeci, G. \& Pertusati, P. 1998. The South Tibetan detachment system in the Rongbuk valley, Everest region. Deformation features and geological implications. Journal of Asian Earth Sciences, 16, 299-311.

Carosi, R., Lombardo, B., Musumeci, G. \& Pertusati, P. 1999a. Geology of the Higher Himalayan crystallines in Khumbu Himal (Eastern Nepal). Journal of 
Asian Earth Sciences, 17, 785-803.

Carosi, R., Musumeci, G. \& Pertusati, P.C. 1999b. Extensional tectonics in the higher Himalayan crystallines of Khumbu Himal, eastern Nepal. In: Macfarlane, A., Sorkhabi, R.B. \& Quade, J. (eds) Nepal and Tibet: Mountain Root to Mountain Tops. Geological Society of America Special PaperS, 328, 211-223.

Catlos, E.J., Harrison, T.M., Manning, C.E., Grove, M., Rai, S.M., Hubbard, M. \& UPRETI, B.N. 2002. Records of the evolution of the Himalayan orogen from in situ $\mathrm{Th}-\mathrm{Pb}$ ion microprobe dating of monazite: Eastern Nepal and western Garhwal. Journal of Asian Earth Sciences, 20, 459-480.

Cattin, R. \& Avouac, J.-P. 2000. Modeling mountain building and the seismic cycle in the Himalaya of Nepal. Journal of Geophysical Research, 105, $13389-13407$.

Colchen, M., Lefort, P. \& Pecher, A. 1986. Annapurna-Manaslu-Ganesh Himal. CNRS, Paris.

DeSigoyer, J., Chavagnac, V., Blichert-Toft, J., Villa, I., Luais, B., Guillot, S., Cosca, M. \& Mascle, G. 2000. Dating the Indian continental subduction and collisional thickening in the Northwest Himalaya: Multichronology of the Tso Morari eclogites. Geology, 28, 487-490.

Edwards, M.A. \& Harrison, T.M. 1997. When did the roof collapse? Late Miocene north-south extension in the high Himalaya revealed by $\mathrm{Th}-\mathrm{Pb}$ monazite dating of the Khula Kangri granite. Geology, 25, 543-546.

Ferrara, G., Lombardo, B. \& Tonarini, S. 1983. Rb/Sr geochronology of granites and gneisses from the Mount Everest region, Nepal Himalaya. Geologische Rundschau, 72, 119-136.

FERRIL, D. 1991. Calcite twin widths and intensities as metamorphic indicators in natural low-temperature deformation of limestone. Journal of Structural Geology, 13, 667-676.

Francheteau, J., Jaupart, C., Xian, J.S., Wen-Hua, K., De-Lul, ., Jia-Cha, B., Huang-Pin, W. \& Hsia-Yeu, D. 1984. High heat flow in southern Tibet. Nature, 307, 32-36.

Goscombe, B. \& Hand, M. 2000. Contrasting P-T paths in the Eastern Himalaya, Nepal: Inverted isograds in a paired metamorphic mountain belt. Journal of Petrology, 12, 1673-1719.

Grujic, D., Casey, M., Davidson, C., Hollister, L., Kundig, K., Pavlis, T. \& SCHMID, S. 1996. Ductile extrusion of the Higher Himalayan crystalline in Bhutan: evidence from quartz microfabrics. Tectonophysics, 260, 21-43.

Grujic, D., Hollister, L. \& Parrish, R.R. 2002. Himalayan metamorphic sequence as an orogenic channel: insight from Bhutan. Earth and Planetary Science Letters, 198, 177-191.

Harrison, T.M., Grove, M., Mckeegan, K.D., Coath, C.D., Lovera, O. \& LEFORT, P. 1999. Origin and episodic emplacement of the Manaslu Intrusive Complex, Central Himalaya. Journal of Petrology, 40, 3-19.

Hauck, M.L., Nelson, K.D., Brown, L.D., Zhao, W. \& Ross, A.R. 1998. Crustal structure of the Himalayan orogen at approximately $90^{\circ}$ east longitude from Project INDEPTH deep reflection profiles. Tectonics, 17, 481-500.

Hodges, K.V., Hubbard, M. \& Silverberg, D.S. 1988. Metamorphic constraints on the thermal evolution of central Himalayan orogeny. Philosophical Transactions of the Royal Society, London, A326, 257-280.

Hodges, K.V., Parrish, R.R., Housch, T.B., Lux, D.R., Burchfiel, B.C., Royden, L.H. \& Chen, Z. 1992. Simultaneous Miocene extension and shortening in the Himalayan orogen. Science, 258, 1466-1479.

Hodges, K.V., Burchfiel, B.C., Royden, L.H., Chen, Z. \& Liu, Y. 1993. The metamorphic signature of contemporaneous extension and shortening in the central Himalayan orogen: data from the Nyalam transect, southern Tibet. Journal of Metamorphic Geology, 11, 721-737.

Hodges, K.V., Parrish, R.R. \& Searle, M.P. 1996. Tectonic evolution of the central Annapurna Range, Nepalese Himalaya. Tectonics, 15, 1264-1291.

Hodges, K.V., Bowring, S., Davidek, K., Hawkins, D. \& Krol, M. 1998. Evidence for rapid displacement on Himalayan normal faults and the importance of tectonic denudation in the evolution of mountain ranges. Geology, 26, 483-486.

Hodges, K.V., Hurtado, J.M. \& Whipple, K.X. 2001. Southward extrusion of Tibetan crust and its effect on Himalayan tectonics. Tectonics, 20, 799-809.

Holdaway, M.J. 2000. Application of new experimental and garnet Margules data to the garnet-biotite thermometer. American Mineralogist, 85, 881-892.

Holland, T.J.B. \& Powell, R. 1998. An internally consistent thermodynamic dataset for phases of petrological interest. Journal of Metamorphic Geology, 16, 309-343.

HubBard, M.S. 1988. Thermobarometry, ${ }^{40} \mathrm{Ar} /{ }^{\beta 9} \mathrm{Ar}$ age geochronology, and structure of the Main Central Thrust Zone and Tibetan slab, Eastern Nepal. $\mathrm{PhD}$ thesis, Massachussetts Institute of Technology.

HubBaRD, M.S. 1989. Thermobarometric constraints on the thermal history of the Main Central Thrust Zone and Tibetan Slab, eastern Nepal Himalaya. Journal of Metamorphic Geology, 7, 19-30.

HubBaRd, M.S. 1996. Ductile shear as a cause of inverted metamorphism: Example from the Nepal Himalaya. Journal of Geology, 194, 493-499.

HUBBARD, M.S. \& HARRISON, T.M. $1989 .{ }^{40} \mathrm{Ar} /{ }^{39} \mathrm{Ar}$ age constraints on deformation and metamorphism in the Main Central Thrust zone and Tibetan Slab, eastern Nepal Himalaya. Tectonics, 8, 865-880.

Hubbard, M.S. \& House, M. 2000. Low temperature dating of high mountain rocks: $(\mathrm{U}-\mathrm{Th}) / \mathrm{He}$ ages from Higher Himalayan samples, Eastern Nepal (Abstract). In: 15th Himalaya-Karakoram-Tibet Workshop, Chengdu. Earth Sciences Frontiers, Beijing, 16-17.

Hurtado, J., Hodges, K.V. \& Whipple, K.X. 2001. Neotectonics of the Thakkhola graben and implications for recent activity on the South Tibetan Fault system in the Central Nepalese Himalaya. Geological Society of America Bulletin, 113, 222-240.

Kosarev, G., Kind, R., Sobolev, S.V., Yuan, X., Hanka, W. \& Oreshin, S. 1999. Seismic evidence for a detached Indian lithospheric mantle beneath Tibet. Science, 283, 1306-1309.

Law, R.D., Searle, M.P. \& Simpson, R.L. 2001. Microstructural and quartz petrofabric evidence for strain paths and deformation temperatures, South Tibetan detachment system, Everest massif, South Tibet (Abstract). Journal of Asian Earth Sciences, 19, 38-39.

Law, R.D., Searle, M.P. \& Simpson, R.L. 2002. Strain, deformation temperatures and vorticity of flow at the top of the High Himalayan slab, Everest massif, Tibet. Geological Society of America Abstracts with Programs, 34, 327.

Le Breton, N. \& Thompson, A.B. 1988. Fluid-absent (dehydration) melting of biotite in metapelites in the early stages of crustal anatexis. Contributions to Mineralogy and Petrology, 99, 226-237.

Lombard, A. 1958. Un itineraire geologique dans l'est du Nepal (Massif du Mont Everest). Memoires de la Societe Helvetique des Sciences Naturelles, 82.

Lombardo, B., Pertusati, P. \& Borgi, S. 1993. Geology and tectonomagmatic evolution of the eastern Himalaya along the Chomolungma-Makalu transect. In: Treloar, P.J. \& Searle, M.P. (eds) Himalayan Tectonics. Geological Society London, Special Publications, 74, 341-355.

Lombardo, B. \& Rolfo, F. 2000. Two contrasting eclogite types in the Himalaya: implications for the Himalayan orogeny. Journal of Geodynamics, 30, 37-60.

Means, W.D. 1989. Stretching faults. Geology, 17, 893-896.

Metcalfe, R.P. 1993. Pressure, temperature and time constraints on metamorphism across the Main Central thrust zone and High Himalayan slab in the Garhwal Himalaya. In: Treloar, P.J. \& Searle, M.P. (eds) Himalayan Tectonics. Geological Society, London, Special Publications, 74, 485-509.

Mu, A.T., Wen, S.H., Wang, Y.K., Chang, P.K. \& Yin, C.H. 1973. Stratigraphy on Mount Jolmo Lungma region of Southern Tibet. Scientia Sinica, 16, 96-111.

MukHopadhyay, B. \& Holdaway, M.J. 1994. Cordierite-garnet-sillimanite-quartz equilibrium 1: new experimental calibration in the system $\mathrm{FeO}-\mathrm{Al}_{2} \mathrm{O}_{3}-\mathrm{SiO}_{2}$ $\mathrm{H}_{2} \mathrm{O}$ and certain P-T-X $\left(\mathrm{H}_{2} \mathrm{O}\right)$ relations. Contributions to Mineralogy and Petrology, 116, 462-472.

MurPhy, M.A. \& HarRison, T.M. 1999. Relationship between leucogranites and the Qomolangma Detachment in the Rongbuk valley, south Tibet. Geology, 27, 831-834.

Nelson, K.D., ZhaO, W. ET AL. 1996. Partially molten middle crust beneath southern Tibet: synthesis of Project INDEPTH results. Science, 274, 16841688 .

Noble, S.R. \& Searle, M.P. 1995. Age of crustal melting and leucogranite formation from $\mathrm{U}-\mathrm{Pb}$ zircon and monazite dating in the western Himalaya, Zanskar, India. Geology, 23, 1135-1138.

O'Brien, P.J., Zotov, N., LAw, R.D, Khan, M.A. \& JAN, M.Q. 2001. Coesite in Himalayan eclogite and implications for models of India-Asia collision. Geology, 29, 435-438.

ODELL, N.E. 1948. Geological and some other observations in the Mount Everest region. In: Tilman, H.W. (ed.) Mount Everest 1938. Cambridge University Press, 143-154.

OWENS, T. \& ZANDT, G. 1997. Implications of crustal property variations for models of Tibetan plateau evolution. Nature, 387, 37-43.

PerchuK, L.L. \& Lavrent'eVA, I.V. 1983. Experimental investigation of exchange equilibria in the system cordierite-garnet-biotite. In: SAXENA, S.K. (ed.) Kinetics and Equilibrium in Mineral Reactions. Springer-Verlag, New York, $199-240$.

Pognante, U. \& Benna, P. 1993. Metamorphic zonation, migmatization and leucogranites along the Everest transect of eastern Nepal and Tibet: record of an exhumation history. In: Treloar, P.J. \& Searle, M.P. (eds) Himalayan Tectonics. Geological Society, London, Special Publications, 74, 323-374.

Polino, R. 1981. Geological Map of the Upper Imja Khola, scale 1:25,000. Firenze, Italy.

Rowley, D.B. 1996. Age of initiation of collision between India and Asia: A review of stratigraphic data. Earth and Planetary Science Letters, 109, $11-23$.

Rowley, D.B. 1998. Minimum age of initiation of collision between India and Asia north of Everest based on the subsidence history of the Zhepure mountain section. Journal of Geology, 106, 229-235.

SCHÄRER, U. 1984. The effect of initial ${ }^{230} \mathrm{Th}$ disequilibration on U-Pb ages: the Makalu case. Earth and Planetary Science Letters, 67, 191-204. 
SEARLE, M.P. 1999a. Extensional and compressional faults in the Everest-Lhotse massif, Khumbu Himalaya, Nepal. Journal of Geological Society, London, 156, 227-240.

SEARLE, M.P. 1999b. Emplacement of Himalayan leucogranites by magma injection along giant sill complexes: examples from the Cho Oyu, Gyachung Kang and Everest leucogranites (Nepal Himalaya). Journal of Asian Earth Sciences, 17, $773-783$.

Searle, M.P. \& Rex, A.J. 1989. Thermal model for the Zanskar Himalaya. Journal of Metamorphic Geology, 7, 127-134.

Searle, M.P., Cooper, D.J.W. \& Rex, A.J. 1988. Collision tectonics of the Ladakh-Zanskar Himalaya. Philosophical Transactions of the Royal Society, London, A326, 117-150.

Searle, M.P., Waters, D.J., Rex, D.C. \& Wilson, R.N. 1992. Pressure, temperature and time constraints on Himalayan metamorphism from eastern Kashmir and western Zanskar. Journal of Geological Society, London, 149, $753-773$.

Searle, M.P., Metcalfe, R.P., Rex, A.J. \& Norry, M.J. 1993. Field relations, petrogenesis and emplacement of the Bhagirathi leucogranite, Garhwal Himalaya. In: Treloar, P.J. \& Searle, M.P. (eds) Himalayan Tectonics. Geological Society, London, Special Publications, 74, 429-444.

Searle, M.P., Parrish, R.R., Hodges, K.V., Hurford, A., Ayres, M.W. \& Whitehouse, M.J. 1997. Shisha Pangma leucogranite, South Tibetan Himalaya: field relations, geochemistry, age, origin and emplacement. Journal of Geology, 105, 295-317.

Searle, M.P., Noble, S.R., Hurford, A.J. \& Rex, D.C. 1999a. Age of crustal melting, emplacement and exhumation history of the Shivling leucogranite, Garhwal Himalaya. Geological Magazine, 136, 513-525.

Searle, M.P., Waters, D.J., Dransfield, M.W., Stephenson, B.J., Walker, C.B., WALKeR, J.D. \& Rex, D.C. 1999b. Thermal and mechanical models for the structural evolution of Zanskar High Himalaya. In: Mac Niocaill, C. \& Ryan, P.D. (eds) Continental Tectonics. Geological Society, London Special Publications, 164, 139-156.

Simpson, R.L. 2002. Metamorphism, melting and extension at the top of the High Himalayan slab, Mount Everest region, Nepal and Tibet. D.Phil thesis, Oxford University.

Simpson, R.L., Parrish, R.R., Searle, M.P. \& Waters, D.J. 2000. Two episodes of monazite crystallization during metamorphism and crustal melting in the Everest region of the Nepalese Himalaya. Geology, 28, 403-406.

Smith, H.A. \& Barriero, B. 1990. Monazite U-Pb dating of staurolite grade metamorphism in pelitic schists. Contributions to Mineralogy and Petrology, 105, 602-615.

Smith, H.A. \& Giletti, B.J. 1997. Lead diffusion in monazite. Geochimica et Cosmochimica Acta, 61, 1947-1955.

SPEAR, F.S. 1993. Metamorphic phase equilibria and pressure-temperature-time paths. Mineralogical Society of America Monographs.

Stephenson, B.J., WATERS, D.J. \& SeArle, M.P. 2000. Inverted metamorphism and the Main Central Thrust: field relations and thermobarometric constraints from the Kishtwar Window, NW Indian Himalaya. Journal of Metamorphic Geology, 18, 571-590.

Stephenson, B.J., Searle, M.P. \& Waters, D.J. 2001. Structure of the Main Central Thrust zone and extrusion of the High Himalayan crustal wedge, Kishtwar-Zanskar Himalaya. Journal of Geological Society, London, 158, $637-652$.

Tonarini, S., Lombardo, B., Ferrara, G. \& Marcassar, P. 1994. Partial melting in the Namche Migmatite of Khumbu Himal (Nepal Himalaya). Mineralogica et Petrographica Acta, 37, 277-294.

VANNAY, J.-C. \& GRASEMANN, B. 2001. Himalayan inverted metamorphism and syn-convergence extension as a consequence of a general shear extrusion. Geological Magazine, 138, 253-276.

Vannay, J.-C. \& Hodges, K.V. 1996. Tectonometamorphic evolution of the Himalayan metamorphic core between the Annapurna and Dhaulagiri, central Nepal. Journal of Metamorphic Geology, 14, 635-656.

Viscona, D. \& Lombardo, B. 2002. Two-mica and tourmaline leucogranites from the Everest-Makalu region (Nepal-Tibet); Himalayan leucogranite genesis by isobaric heating? Lithos, 62, 125-150.

VISKUPIC, K. \& HodgeS, K.V. 2001. Monazite-xenotime thermochronometry: methodology and an example from the Nepalese Himalaya. Contributions to Mineralogy and Petrology, 141, 233-247.

WAGER, L.R. 1934. A review of the geology and some new observations. In: Ruttledge, H. (ed.) Everest 1933. Hodder \& Stoughton, London, 312-336.

WAGER, L.R. 1965. Injected granite sheets of the Rongbuk valley and the north face of Mount Everest. In: D.N. Wadia commemorative volume. India Mining, Geology and Metallurgy Institute, 358-379.

Walker, J.D., Martin, M.W., Bowring, S.A., Searle, M.P., Waters, D.J. \& HoDGES, K.V. 1999. Metamorphism, melting and extension: Age constraints from the High Himalayan slab of Southeastern Zanskar and Northwestern Lahoul. Journal of Geology, 107, 473-495.

WANG, Z. \& ZHEN, X. 1975. Imbricate structure in the northern slope of Jolmo Lungma and discussion on the uplift of the Himalaya. In: Scientific exploration of Jolmo Lungma. Science Publishing House, Beijing, 199-221.

Wei, W. \& Unsworth, M. 2001. Detection of widespread fluids in the Tibetan crust by magnetotelluric studies. Science, 292, 716-718.

Weinberg, R.F. \& SEARLe, M.P. 1999. Volatile-assisted intrusion and autometasomatism of leucogranites in the Khumbu Himalaya, Nepal. Journal of Geology, 107, 27-48.

Wu, C., Nelson, K.D., Wortman, G., Samson, S., Yue, Y., Li, J., Kidd, W.S.F. \& Edwards, M.A. 1998. Yadong cross-structure and South Tibetan Detachment in the east central Himalaya $\left(89^{\circ}-90^{\circ} \mathrm{E}\right)$. Tectonics, 17, $28-45$.

YIN, C.H. \& KuO, S.T. 1978. Stratigraphy of the Mount Jolmo Lungma and its north slope. Scientia Sinica, 21, 629-644.

Zhao, W., Nelson, K. D. \& Team Project INDEPTH 1993. Deep seismic reflection evidence for continental underthrusting beneath southern Tibet. Nature, 366, $557-559$. 